principles, as the realization of a single linguistic imperative, or for that matter a single cultural one. Selection becomes a matter of authorial taste and resourcefulness, and it is precisely here that the search for the correct path for the literary language culminates. Hunting for paths is replaced by the pursuit of the best linguistic means to embody the concrete goals of the author in the context of one particular text. This was achieved by the stabilization of the literary language, as general theoretical problems were now transformed into issues of literary stylistics.

And so in the conflict between archaists and innovators we see not a clash between Europeanized and traditional culture, but one of literary trends, a conflict that may be situated fully within the framework of Europeanized Russian culture. The very narrowing of the issue from a broad cultural to an intraliterary one testifies to the fact that the cultural antagonism that shook Russia during the Petrine and post-Petrine periods had taken a secondary place, if it still existed at all. Of course, on the larger Russian scale this antagonism was still there, and the lower levels of society continued to view the world in far different categories from those of the educated class. However, for the dominating culture those other categories no longer held any interest, and ceased to be a factor in its development. The dominating culture attained that level of self-sufficiency at which cultural oppositions merge with the battle between literary trends. This circumstance prepared the ground for the synthesizing stabilization of the Russian literary language which Pushkin was able to accomplish. But this development also brought the literary language into a new phase of development, beyond the parameters we set out to examine in this book - the history of the harmonization of European and traditional values in Russian culture and the literary language. The debates between archaists and innovators might have served as the epilogue to this investigation, were it not for one arena of literature in which the struggle between secular and religious traditions retained its importance: the religious literature of the first half of the nineteenth century.

\title{
2. Slavonicizing Purism and Its Reconceptualization in Religious Literature
}

The cultural and linguistic synthesis of the second half of the eighteenth century had two heirs: the traditions of secular and of religious literature. Brought together in synthesis by the force of state unity, they 
again separated after its disintegration. The social and cultural differences that contradicted the universalism of the literary language and that had only been hidden for a while by the Petersburg mirage again began to declare themselves, both in the properly cultural sphere as well as in that of language. As we have seen, each of these traditions had its own values and began to reconsider the legacy of the previous period in light of them. At first both traditions experienced some perplexity as to what direction to chose. In secular literature this manifested itself in the debates between the archaists and innovators. Religious literature did not experience such a polarization, although the problem of choosing a new path did lead to a series of collisions and controversies. The question arose first of all of defining the nature of religious education, that is, defining the kind of spirituality and cultural worldview of future members of the clergy.

In the eighteenth century education took on a professional and corporate character: people were trained for professions, and only those who were eligible by social position could choose a given profession. Education was designed to continually reproduce society's division into occupations that had been established by the state, creating a social structure which like any well-constructed mechanism required only the replacement of worn out parts (e.g., the son replaces the father) (see Vladimirskii-Budanov 1874). Religious education was designed for children of the clerical estate and was meant to prepare them for careers in the church. The estate-oriented character of education generated the prerequisites of a closed, caste culture (see Znameskii 1881; Freeze 1977, 210-15), although during the period of cultural synthesis the ideal of one single culture stood in the way of bringing this into being. A single unified culture had been part of absolutist state policy, and the entire educational system had been called to put it into practice.

Religious seminaries had acquired the character of classical colleges, where the study of the classics and classical rhetoric were central. This was precisely the case with the Trinity and Vifanskii seminaries which were under the supervision of Metropolitan Platon (Levshin) and served as models for other ecclesiastical educational institutions (cf. Smirnov 1867). There were specific differences from secular education and culture but they were not at all due to a conscious rejection or endorsement of their own spiritual values but rather to a degree of conservatism which perpetuated aspects of the Baroque educational model that had been formulated in seventeenth-century Europe and from there transplanted into Russia (cf. Lappo-Danilevskii 1990; Zhivov and Uspenskii 1984, 230-4). Moreover, there were attempts to introduce the teaching of modern European languages into seminaries and classes aimed at familiarizing students with the latest works of European literature (cf. 
Titlinov 1916, 842-3). ${ }^{14}$ Only toward the end of the eighteenth century did the tendency arise among a certain part of the clergy to praise their own learning, contrasting it to the often superficial knowledge of gentry society.

The partial liberation from the state's ideological monopoly made obvious the need to bring clerical education more into line with real social needs and to make it relevant to what the students would face upon graduating seminary. The current situation in which Latin and the Latin curriculum were to define the outlook and future activity of the seminarists was recognized as abnormal. "Today's curriculum (kurs) right through to philosophy is not a curriculum of the sciences, but only of Latin literature," wrote Evgenii Bolkhovitinov (Florovskii 1937, 113). And Filaret (Drozdov), evaluating the period retrospectively, wrote that "Before the reform of the church schools some of them considered their claim to fame in their superior teaching of the Latin language. The clergymen from there knew pagan writers better than holy and ecclesiastical ones, spoke and wrote Latin better than Russian, and were better able to shine within a circle of scholars by means of select phrases in a dead language than to illuminate the people with a living understanding of the truth" (Chistovich 1894, 272).${ }^{15}$ The time had come for a reform of religious education, and a special committee was formed for that purpose in 1807, and in 1809 the Commission on Church Schools. Projects were drawn up for a new type of school, and these projects revealed the diversity of opinion that had arisen as a result of the disintegration of the cultural synthesis of the preceding period.

14 Characterizing the theological, philosophical and literary views of Platon Levshin, R. L. Nichols describes the direction religious education took in the second half of the eighteenth century: "Even this brief sketch of Platon's outlook, intellectual preoccupations, and contributions to the education of several generations of students makes clear that leading churchmen breathed much the same air as that making up the secular cultural and intellectual atmosphere of Catherine's reign. In fact, the problem was not the isolation of educated churchmen from the mainstream of Russia's westernization. Rather, as a consequence of the almost wholly western education which the clergy received, and in light of the ideals it inspired in the church's leading representatives, there was a real danger that the church might become simply a western institution or (in view of the state's use of the seminaries for its own benefit) an instrument of secularization" (Nichols 1978, 78).

15 The biography of Avgustin Vinogradskii strikingly illustrates the importance of a Latin education in a cleric's career. As a student in the Moscow Academy, his poetry in Latin attracted the attention of Platon. He dedicated his first poem to the metropolitan in honor of his name day (Nov. 18, 1788) and was invited to dinner with him, an extraordinary honor for a student. Avgustin's next poems so impressed Platon that he ordered one to be printed and distributed to all religious educational institutions; one copy of these "golden" verses (Platon's word) was actually printed in gold, and Platon himself inscribed it to the author, also in gold (Avgustin Vinogradskii, 1856, v-viii). In 1804 Avgustin became Bishop of Dmitrovsk, Platon's assistant (vikarii), and after Platon's death, Archbishop of Moscow. 
There may have been consensus on the need to harmonize the school program with society's needs, but conceptions of just what that society was turned out to be quite diverse. On the one hand was educated secular society, and on the other, the entire remaining mass of the population. The majority of graduates would be working with the latter, but it was not accepted or customary to take this into consideration. ${ }^{16}$ Religious education did not want to lag behind the secular; keeping pace with it had become customary during Catherine's reign. Furthermore, notions of culture continued to be associated with social position, and taking into consideration the needs of the "simple folk" might entail the loss of even those insignificant privileges that separated the clergy from the lower classes and brought them closer to the gentry.

Considerations of this sort clearly played a role for the influential Metropolitan Platon Levshin. In his instructions to the clergy he emphasized that clergymen should associate with the social elite instead of with just anyone, to instill respect for themselves (Platon Levshin 1775, 33). They clearly did not receive enough respect, and the gentry certainly did not endorse their rise in social status. The character of their education was to support their social pretensions, and this included, in particular, the knowledge of languages. The connection of foreign language learning with social privilege, the loss of which could mean that the clergy might finally merge with the lower classes, was a reason for Platon's opposition to have teaching in seminaries be in Russian. When this question was posed in the Synod in 1800, Platon wrote to Amvrosii Podobedov:

I do not advise that lectures be given in Russian in our schools. Even so our clergymen are considered almost ignoramuses by foreigners because we don't know either French or German. But we maintain our honor by speaking and corresponding in Latin. If we will study Latin the way we do Greek, then we will lose this last bit of honor, insofar as we won't speak or correspond in any language at all. I ask you to forget this idea. In our tongue there are few even classical books. The perfect knowledge of Latin also greatly aids oratory in Russian. I am writing this on the collective advice of the rectors - of the academy, the Trinity [Seminary], and the prefects, and the Right Reverend Serafim. (Smirnov 1867, 340-1) $)^{17}$

16 Of course it was inevitable that this was understood on some level. It is remarkable, for example, that in 1798 the Synod "recognized the need to have the Medical College compile a book for rural clergymen in which... would be described the number and character of sicknesses of the common people whose responsibility it is the clergy's to treat" (Chistovich 1857, 118). In the cultural sphere, however, Baroque - Enlightenment traditions continued to reign, and clerical students' future occupations were not reflected in their education.

17 This desire not to lag behind secular learning was the reason for the spread of French language and culture among the clergy. Karamzin, describing his visit to the Trinity-Sergius Lavra 
This sort of consideration also lay at the basis of the projects for reform which one way or another tried to take into account the achievements of European secular culture. This may be especially seen in the selection of literary models which students learning oratory were supposed to follow. Differences of opinion on this point were extremely meaningful. In proposed regulations for spiritual academies drawn up [461] by Feofilakt Rusanov in 1809 , the models for teaching the theory of aesthetics were listed as Cicero, Horace, Longinus, Quintilian, Dionysius of Halicarnassus, and as guides "from the moderns" were suggested "La Harpe, Gérard, with the addition of [excerpts from] Montesquieu, d'Alembert, Marmontel, Fénélon, Cardinal Mori, Chateaubriand, Burke, Batteux, Blair, Meissner, Eschenburg and L. de Lévizac" (Chistovich 1857, 206). This list makes clear both the desire not to lag behind secular education as well as a definite partiality for Enlightenment tastes that was the legacy of Catherine's reign. The same tendency is evident in the project that M. M. Speranskii proposed (before he became a government official, he taught a course in advanced oratory in the Alexander Nevskii seminary). Here "of the moderns" were named: "Fénélon, Rollin, Boileau, Sulzer, Baumgarten, Diderot, Buffon, and especially Beccaria" (Chistovich 1894, 122).

These proposals met resistance from the Academy directorate and Filaret Drozdov (at that time inspector of the Petersburg Spiritual Academy). In particular, Filaret wrote, "Who then are these preceptors in literature? They are Buffon, Du Marsais, Beccaria, naturalists - [all] advocates of Voltairean philosophy" (Chistovich 1894, 123). A document from the academy directorate argued that "In $\S 116$ [of the proposed regulations] a student is required to recite, among other things, the opinion of Plato, Boileau, and Buffon concerning the fine arts (ob iziashchnom). Plato's dialogue called the Symposium (Simposion) is more enticing than edifying. Boileau did not add anything positive to Horace's epistle on poetry, except for information

in 1802, noted: "The Trinity seminary is one of the main religious schools in Russia. Apart from ancient languages, they also teach French and German here. This is admirable; in order to preach, one should know Bossuet and Massillion. Some of the monks here spoke with me in French, and the important teachers mix French phrases into their conversation. They showed me how gracious learning is; they walked with me and showed me everything with an air of sincere consideration. Education gives a person a kind of nobility, no matter what his condition" (Smirnov 1867, 483). Concerning the radical turnabout in attitude toward secular education among the clergy that took place in the 1810's-20's may testify the fact that in his "Staraia zapisnaia knizhka" [Old Notebook] Viazemskii describes as an oddity a priest from Moscow who "was rather educated and so knowledgeable in French that when he walked through the church past young ladies carrying the censer he would say "pardon, mesdames"” (Viazemskii, VIII, 71). 
about several French writers; his interpretation of Longinus does not deserve much attention; and the name of this writer should not be met in any good book, not to mention in the religious regulations. What discoveries Buffon made about the fine arts, nothing is known. For these reasons would it not be preferable instead of Plato to recommend Dionysius to students, instead of Boileau - Longinus, and instead of Buffon - Blair, who is known to every literary man for the merit of his rules?" (ibid). ${ }^{18}$

Thus without making their arguments explicit concerning the special nature of religious literature, the opponents of the "modernist" program raised objections to listing authors whose only reason for being on the list was as representatives of contemporary secular culture. In particular, Filaret proposed the following formulation for the regulation in question: "The professor of the class in literature should present the students with opinions about the beautiful (iziashchnoe) from the best writers who touched on the subject, who from the ancients are: Plato, Aristotle, Cicero, Horace, Quintilian, Longinus; and from the moderns - Fénélon, Rollin. Other modern authors must be used with care and perspicacity, because some of them have tried with brazen and destructive abstract reasoning to tear the beautiful away from the true and the good" (ibid, 123). In this way, even as they recognized the importance of European models, Filaret and those who agreed with him refused to accept the evaluations and opinions of secular culture (cf. Nichols 1978, 79-84). This was a significant moment, for with time Filaret's position won out; religious culture was heading for a conscious break with the secular. This gradually led to the creation of a religious educational curriculum that was directly opposed to the content and aims of a secular upbringing.

A similar process of cultural self-definition took place in language as well. The heritage of the period of cultural synthesis was the unity of the secular and religious literary language. The language of religion could now follow in the tracks of secular literature, and clergymen, addressing a secular audience, strove to write and speak in its tongue. This tendency received additional stimulus with the spread of mysticism and extra-confessional pietism. Due to the deep inner connection between mysticism and pietism, on the one hand, and Sentimentalism, on the other (cf. Florovskii 1937, 116-7), the language of mystical and pietistic literature was close to that of Sentimentalism, that is, precisely the language of Karamzin and his followers.

$18 \quad$ It is curious to juxtapose this criticism of French writers with the fact that in 1772 Platon Levshin had purchased a library for the Trinity Seminary that included Boileau, Corneille, Montesquieu and Voltaire, and with money that was hard to come by (see Smirnov 1867 , 378). 
In the late eighteenth century such a rapprochement presupposed a certain spiritual frame of mind on the part of the clergy which stressed religious "feeling" as a counterweight to "scholastic reason." This frame of mind was characteristic, for example, of M. M. Speranskii (see his psychological portrait in Florovskii 1937, 138-9); it was clearly reflected in his Rules of Advanced Oratory of 1792. As V. D. Levin notes, the language of this work "amazes one by its closeness to the language of Karamzin and his "school" (Levin 1964, 115). Linguistic similarity here was a natural consequence of the similarity of theoretical principles: Speranskii writes in the tradition of Vaugelas" purism, calling usage "a little tyrant" and asserting that "the god of good taste imposes" on the writer "the incontrovertible law of being clear" (Speranskii 1844, 161, 173). ${ }^{19}$ At the start of the nineteenth century, mysticism and pietism became a kind of official ideology; correspondingly, using the "worldly" language (following the stylistic norms established by secular literature in literary practice) might not even have been dictated by convictions but by conformism. Texts of this kind have not been studied, and so it is hard to judge how well established this trend is in religious literature. ${ }^{20}$

19 V. V. Vinogradov $(1949,206)$ puts this into the context of the Karamzinian struggle against high style and the book Meditations on Oratory in General, and Especially on Preaching. From the Works of Mr. Abbot Trublet, Translated in the Voronezh Seminary... (Trublet 1793), the translation of a French guide to oratory done by Evfimii Bolkhovitinov (the future Metropolitan Evgenii). Indeed the book contains a series of protests against the tradition of Baroque rhetoric. [...] However, there is no special connection with Karamzinian ideas here at all. In Evgenii's literary views (as shown, for example, by his correspondence with Derzhavin) he was a conservative Classicist. Hence his attacks on Baroque style sermons (and the general call for "naturalness") makes more sense in connection with Sumarokov's doctrines. That these doctrines were used by a religious writer and applied to religious literature indicates precisely the perception of religious and secular literature as a unity, guided by the one and same set of stylistic criteria (this is the position of the French abbot Bolkhovitivov translated [Trublet 1793, 78]). This perception was typical of the period of linguistic and cultural synthesis (and in this sense, Bolkhovitinov, as in many other respects, was an heir to the age of Catherine) but was by no means typical of the Karamzinists. One may also find analogous statements in Gedeon Krinovskii and Platon Levshin, whose theoretical linguistic views and practices also had nothing to do with Karamzin. Vinogradov does not distinguish between the commonplaces of European stylistic theory (which could appear both in Karamzinist writings as well as those of their predecessors and opponents) and original statements that relate to the Russian material, and this leads him to incorrect conclusions.

20 It is evident that among clergy in the capitol who wanted success with their secularized congregations, the "worldly" trend was rather well established. Characteristic in this sense is Viazemskii's story about the priest with the predilection for French (see note 17). "He didn't like Metropolitan Filaret and criticized his language and style. Dmitriev... defended him. 'For goodness sake, your Excellency,' the priest once said to him, 'isn't it the languge in which your own "Fashionable Wife" is written?"” (Viazemskii, VIII, 71). 
Whichever way it was, this was not the most important trend. At this same period, in the early years of the century, another tendency was developing based on the premise that it was not befitting the language of religious literature to emulate the secular. Parity with the norms of fashionable literature began to appear as a disregard for religious values and a vain chasing after worldly approval. As in education as a whole, a rift between secular and religious literature is revealed in its language. Refusing to follow the innovations of secular enlightenment, religious literature claims the Slavenorossiiskii language for itself, the language that sounded in Lomonosov's odes and of Platon's sermons alike. This language is now perceived as especially fitting for religious literature, combining as it does the "churchiness" of Slavonic and the comprehensibility of Russian. In this way, the literary principles advanced by Trediakovskii and Lomonosov were preserved and further developed in Russian religious literature. Of course, we are not speaking here of preserving all of the norms of the earlier language; insofar as grammatical norms had already been formulated by the start of the nineteenth century, the specifics of the language's stylistic variants ceased to be connected to grammatical elements, and were defined instead by vocabulary and phraseology. It was precisely in these areas that the language of religious literature preserved "Slavenorossiiskii" principles.

As said earlier ( $\S$ III-3.1), the development of Slavenorossiiskii turned Church Slavonic into an exclusively liturgical tongue, a language of cult. The natural result of such a view was to translate the Bible, as a book for reading, from Church Slavonic into Slavenorossiiskii, the Russian literary language, while preserving Church Slavonic in the liturgy. With the establishment of the Bible Society, work on such a translation began on a broad scale, moreover, as justification for it the same explanation of the obscurity of Church Slavonic was put forward as had at one time been expressed in the Spiritual Regulation (§ I-2.1), and then repeated by Platon Levshin and Gavriil Petrov as the reason for creating all religious literature in Slavenorossiiskii. Speaking of this translation, Alexander I asserted that "by itself it will remove the seal of an incomprehensible dialect which to this day bars many Russians from Jesus' Gospel, and it will open up this book even for the nation's children (dlia samykh mladentsev naroda), from whom it has been hidden not by design but by the darkness of time" (Florovskii 1937, 154; Chistovich 1899, 25, 34).

Those who took part in the translation included not only, and not principally, adherents of Alexandrine mysticism as much as zealots of religious enlightenment (Filaret Drozdov, Gerasim Pavskii, and others), for whom the translation seemed a necessary condition for educating the nation 
in Orthodoxy. The later rift between Filaret and Pavskii and reproaches against Pavskii for theological "neologism" (Batalden 19^^) do not relate to this period; they have nothing to do with their common efforts on behalf of Bible translation, which by no means lay outside the Orthodox tradition. For Filaret and those who agreed with him this was just as essential a step as changing the language of religious education from Latin to Russian; both were aimed at making the clergy's pastoral work more effective. Filaret and his associates believed that the subordination of the Orthodox church to the state's ideological and cultural monopoly in the eighteenth century was one of the main reasons why the clergy had lost influence with a significant portion of the population (those who had joined the Schism or sects, or who had simply lost interest in religion). From Filaret's point of view, this process was explained not by the church's connection to the authoritarian structure of secular power but by insufficient religious enlightenment, subordination to secular models and lack of pastoral work (here as one cause the scholastic character of religious education was cited). Filaret wrote that "we need a kind of missionaries to the Orthodox people" (Filaret I $\wedge$, , $\wedge \vee \vee$; cf. similar statements by Archbishop Evgenii Kazantsev in Malov $\vee$, $\backslash \wedge \vee \tau)$. For the work of enlightenment a comprehensible text of the Bible was needed.

Slavenorossiiskii allowed for making the biblical text comprehensible without repudiating the beauty of the "Slavonic" model (at least, according to the project's defenders). Here the stylistic principles developed during the period of cultural synthesis retained full relevance. In the rules for the translation which Filaret Drozdov compiled in 1816 the orders were, in translating from Greek, to use "Slavonic words" "if they are closer to the Greek than the Russian, but without producing obscurity or clumsiness," or "if the corresponding Russian words do not belong to the pure bookish tongue" (that is, to the Russian literary language whose norms were established in the latter half of the eighteenth century). At the same time, the extremes of Slavonicizing purism were to be curbed. "The grandeur of holy writ," noted Filaret, "is in the power of the words and not in their external brilliance; it follows from this that one should not become too attached to Slavonic words and expressions for the sake of their apparent gravity" (Chistovich 1899, 27).

However, insofar as the translation was the project of the Bible Society it was carried out in the context of the religious and administrative reforms of Alexander I and A. N. Golitsyn, as one of various undertakings of the so-called "special ministry" of the Ministry of Religious Affairs and Popular Education created on October 14, 1817. It could be perceived therefore as an encroachment of the secular power, indifferent or even inimical to Orthodox traditions, on the church's independence (or whatever 
remained of it), and as interference in church doctrine. Because of this, the struggle to preserve Orthodox teaching and piety turned out to entail rejecting translation of the Bible into Russian. For the opponents of the translation, the linguistic position was identified with the cultural one (although, as has been suggested, in reality such a connection was lacking). For leaders of the church movement like Archimandrite Fotii or Metropolitan Serafim, Russian, when juxtaposed to Church Slavonic, seemed an emphatically worldly and secular language, while Church Slavonic was perceived as sacred (characteristically, Fotii wrote his own compositions in a language that should probably be characterized as hybrid Church Slavonic). Hence translating the Bible from Church Slavonic into Russian appeared as a kind of sacrilege. In 1824 the Bible Society ended its existence, and copies of the Russian translation of the Pentateuch which hadn't yet been sold were consigned to the flames.

Cultural and linguistic factors, of course, weren't the only things that came into play here. In particular, this touches Shishkov's position, as he played a significant role in the reversal of 1824, although linguistic considerations probably were not the least in importance. As he considered Church Slavonic and Russian as having a single nature, he thought that using Russian required special justification. This could have been worldly (civic) content or exhortatory address to the people in a sermon. Without sound basis translating from Church Slavonic into Russian represented a senseless profanation of the holy tongue. On the Bible translation Shishkov wrote that

A language isolated from daily life is proper for the church. In the general opinion of pious people the Slavonic word of the Psalter somehow acts more strongly on the soul and inspires more reverence than the Russian Psalter. This is quite natural because the Slavonic language at the present time has not been defiled either by the expression of shameful passions, nor by idle verbiage, nor by explanations of vain actions. This all remained the lot of the language of daily life (iazyk obshchezhiltel'nyi). In the Slavonic tongue the simple folk hear only what is holy and edifying. The moderate obscurity of this language does not overshadow the truth, but serves it as a kind of elemental setting. Remove this veil, and then everyone will interpret the truths of writ according to his own notions. (Chistovich 1899, 302-3)

As this quote suggests, another reason for opposition to the Bible translation was the fear of free interpretation of the Bible. The concern was that independent study of the Biblical text could lead to deviation from Church doctrine $^{21}$ or that the people would derive "false ideas" about state power. ${ }^{22}$

\footnotetext{
$21 \quad$ This argument had been used by Catholics who opposed unrestricted reading of the Bible and having the Bible translated into national languages (cf. § I-2.1).

22 These opinions were also stated during arguments about teaching theological subjects in Russian. Metropolitan Filaret wrote to Filaret Gumilevskii: "On teaching theological lessons
} 
But be that as it may, for the linguistic program of religious literature the impact of the 1824 reversal was substantial. It emphasized the significance of Church Slavonic for religious literature; while religious literature was not to become Church Slavonic once again, Church Slavonic was held up as the obligatory model of correctness and purity. Notably, Filaret Drozdov's Orthodox catechism, which had been published in 1823 and written wholly in Russian, was removed from sale and when it was republished not only was Church Slavonic restored in biblical citations and prayers, but the entire text was Slavonicized (mostly its lexicon). The linguistic principle which was asserted in this way remained obligatory for religious literature throughout Nicholas I's entire reign, and defined-at least in terms of language - the opposition between religious and secular literature, which enjoyed a certain official support.

This differentiation of religious and secular traditions, underscored (rather than created) by the events of 1824, had still another aspect. As noted, religious education was estate-oriented, and the differentiation of religious and secular traditions now extended to secular and religious learning. In 1814, Filaret Drozdov gave his response "On the Synopsis of the Priestly Monk (hieromonakh) Feoktist Orlovskii, Teacher of Rhetoric at the Moscow Academy." Filaret commented that "the synopsis is written too much in the secular spirit," asserting that "The doctrine concerning the grace of truly natural objects does not belong to the category of literature, nor to the state of the writer" (Chistovich 1894, 138). What is curious here is not that the study of beauty in nature is being excluded from aesthetics, but that natural grace is defined as something with which the clerical estate is not to concern itself. In 1812 the senator Ivan Lopukhin complained about the ecclesiastical censorship: "Now look what they've latched onto today-not only not to permit what they find objectionable (according to their inadequate, perverted, or false idea of true spirituality), but this, they say, may be good, but is written by a lay person, and this we should have written this, so it dishonors us - so we won't let it through" (Dubrovin 1895: 76).

The perception of religious literature and education as belonging to a separate estate was characteristic of the whole first half of the nineteenth century. ${ }^{23}$ In 1802, for example, the church censor did not want to accept the

in Russian for the convenience of explanation and about liberating Orthodox theology from the pagan and papist Latin language, I made a proposal in 1828 or 1829. Do you know who objected? Dibich. He had the idea that theological debates in the native language would spread divisive ideas among the people" (Filaret 1872, 50).

23 This perception was not, it seems, characteristic of the eighteenth century, although one can't ignore various early signs of it. Thus in 1768 Kir'iak Kondratovich made an application 
Mesiatseslov (church calendar) published by Glazunov and Kapustin "by reason of their status, that they are laypeople (svetskie)" (Kotovich 1909, 13). The same attitude may be seen in Metropolitan Filaret's letter to the OberProcuror of the Synod A. P. Akhmatov of May 1, 1862, in which the issue concerned permission for a lay person to publish saints lives in a supplement to a weekly magazine. Although Filaret departs from the hard line of the previous reign, the view that religious literature is the domain of authors who belong to the clergy emerges very clearly. "The reasoning is just," writes Filaret, "that members of the clerical rank are more dependable in compiling saints lives, as both their education and life prepares them for this. But the Most Holy Synod does not strictly hold to this argument" (Filaret, SMO, V, 257). ${ }^{24}$

Just as religious education and religious literature began to be perceived in terms of corporate values, so too the literary language. Church Slavonic words which were part of Slavenorossiiskii, could, in the appropriate semantic situation, be regarded as "religious" and hence as the exclusive possession of the clergy. When in 1808 Shishkov presented the Russian Academy with his Attempt at a Slavonic Dictonary, Amvrosii Podobedov and Feofilakt Rusanov remarked in their review that the word "благодать" [mercy] should never be used... in secular documents; but theologians, preachers, and in general all those who teach morality in the church may use it in their explanations when appropriate and needed" (Derzhavin, IV, 780). The ecclesiastical reviewers thus not only asserted the sacred character of

to Platon Levshin for support of his lexicographical work as a translator and requested remuneration for it. Complaining of the lack of such support, he wrote that: "One possible argument [against] my request might be that either your own subordinates can translate the books of the Holy Fathers, and that the clergy aren't interested in Cicero's speeches, and the same about printing Homer, or that they are satisfied with the lexicons that already exist" (Tikhonravov 1858, 232). Notably, Kondratovich is writing not about the clerical estate, but about Platon's "subordinates," and his exclamation about the non-religious character of Cicero and Homer is mostly for effect. In the first half of the nineteenth century a secular author's suitability to translate patristic literature would not even have been considered, whereas translations of Homer or Cicero were were regarded as obviously alien and unnecessary for clergymen.

24 In the second half of the century, Filaret Gumilevskii wrote in the foreword to his Survey of Russian Religious Writing (Obzor russkoi dukhovnoi literatury): "Today we do not dispute that works of sincere Christian piety, whoever their authors, should take their place in the history of religious literature. To whom would now occur the idea of insisting that a work on the Holy Gospel is not religious because it is the work of a Chebotarev?" (Filaret Gumilevskii, 1884, II, 277f; the reference is to Prof. L. A. Chebotarev's Tetraevangelion or Union of the Four Evangelists [Chetveroevangelie, ili svod chetyrekh evangelistov] of 1803). It follows from Filaret's words that in the first half of the century for many clerics lay status automatically prevented someone from authoring religious literature. 
the word, but also insisted that it be used exclusively by church people. The Slavonicized language was thus to function as the property of the clerical estate (cf. Zhivov 1981, 80; Zhivov 1984a, 369).

As secular literature broke with the "Slavenorossiiskii" heritage, so did this attitude spread to secular society. What was first asserted by the Kazamzinists later gained wide acceptance. When in 1811 Shishkov gave his "Speech on the Love for the Fatherland" at his literary society, the Colloquium, I. I. Dmiriev remarked: "If only for the metropolitan" (Khvostov 1938, 378). This appears to refer to the Slavonicizing language of the speech rather than its content, which was not specifically religious; Slavonicized language thus served as the distinguishing mark of belonging to the clergy. It should be noted that while this view might not provoke protest from the Karamzinists, who rejected the previous literary tradition, it was unacceptable to the Shishkovites. For them "Slavenorossiiskii" was the normal literary language, and the use of words taken from church books in secular literature was routine and fully justifiable. For this reason, Derzhavin, after learning of the clergymen's objections to Shishkov's dictionary (together with criticism of the improper use of the word благодать, they had also written that the epithet неблазный [foreign to temptation] "belongs exclusively to the Blessed Virgin" - Derzhavin, IV, 780), penned the line “Дом благодатныя, неблазныя Добрады" (Home of Dobrada, graceful and foreign alien to temptation) in his 1808 poem "Obitel' Dobrady" (Dobrada's Abode) that was addressed to Empress Mariia Fedorovna. (II, 693). In his explanatory notes to the poem he recounted the incident with Shishkov's dictionary and wrote that "Since the author considered their opinion unjust, he made bold to put these words into his composition. The censor let them though, the public accepted them, the Synod was silent; consequently they may be used anywhere, if the proper serious theme and those who are addressed are taken into consideration" (ibid). ${ }^{25}$

To the extent that the cultural and linguistic synthesis of the second half of the eighteenth century was becoming an alien and half forgotten tradition for the cultured elite, the "Slavenorossiiskii" literary language of the clergy began to be perceived as alien, artificial, and obscure. In 1838 the Ober-Procurator of the Synod Count Protasov told Nikodim Kazantsev, whom he had called to Petersburg in connection with new reforms in religious

\footnotetext{
25 Derzhavin was basing himself here on the eighteenth-century literary tradition in which secularized use of the word благодать was very common (cf. Zhivov 1981, 81); the source of this usage was apparently the correlation between the Russian благодать and the French grâce.
} 
education, that "Your theology is very high-flown. Your sermons are lofty. We don't understand you. You don't use the people's language... You've chosen for yourselves some kind of private language, like doctors, mathematicians, or sailors. You can't be understood without help. Talk to us in a language we understand, teach us God's Law so that the very last peasant will understand you right off" (Chistovich 1894, 322). He was clearly speaking about the clergy's literary language, which he was equating to a closed, professional, corporate jargon. This differentiation of the secular and religious linguistic traditions was also reflected in the view of the language that was current among the clergy, in their perception of particular linguistic phenomena, and in their literary practice. In the collisions that were played out here we may see the last reflection of the cultural-linguistic oppositions that had been created by the Petrine reforms.

\subsection{The Understanding of Purist Rubrics}

In this way the cultural and linguistic synthesis of the second half of the eighteenth century was preserved in the literary language of the clergy. Correspondingly the purist conception that lay at the heart of the idea of "Slavenorossiiskii" was also perpetuated. The scheme which Amvrosii Serebrennikov proposed at the end of the century (cited above, § III-3.2) in essence repeated itself in the 1840s in Ia. Amfiteatrov's course in homiletics, which faithfully reflected the clergy's purist views of the first half of the nineteenth century. Amfiteatrov likens Church Slavonic to "biblical" language, deeming the Bible to be its main model (Amfiteatrov, II, 132). On harmonizing this language with Russian he writes:

Can the use of the Biblical language be brought into line with the spirit and purity of the modern national language? This may be done quite easily, because: a) The genius of the original languages of Writ is so natural, broad, and pliant that it may be conveniently applied to any language without violating either its own nature or that of the other language. b) It does not particularly contradict either the analogizing or idiomatic qualities of our national language, because of the mutual union of kinship that was effected in ancient times and strengthened over the ages. c) Our Biblical language is not a dead one, on the contrary, it is fully alive and has been operative in epochs that are most sacred for the people and [it is still used] for the liturgy in the church, in the sacraments, in domestic and everyday occasional offices. d) A great number of words from the Biblical language have already migrated into the people's speech (and continue to do so), without the consent of grammarians and philologists, and these words have 
earned the invincible right of citizenship. e) Assimilated by the people, the Biblical language imparts grandeur, naturalness, richness and newness to the national tongue. (ibid, 119-120)

These same ideas were the basis for Trediakovskii's and Lomonosov's Slavonicizing purism - the correspondence between the nature of Russian and that of the ancient tongues, with Greek as the source of this correspondence, and the language's special linguistic richness that results (§ III-2.1).

Amfiteatrov writes specifically on the relationship between Church Slavonic and the contemporary literary language:

The main relation of this language to today's national tongue is the same as that noted of the Biblical language. Of their frequent contact one may add the following: however strong the calls of our modern writers for the purity of the Russian language, however just the demand that we write in a contemporary, living conversational language, we see that Slavonicisms, in spite of all contentions, triumphantly penetrate into our living contemporary speech. As soon as the subject of writing goes beyond the bounds of everyday objects, as soon as one's thought assumes a serious or elevated cast - the phrases and form of Church Slavonic speech immediately come to mind to express these things and ideas. To change this form would mean to deprive the word of its value; not to use it would be to deprive the thought of its value. It is for this reason that sometimes even the most ardent purists, esteeming the merit of their ideas, seemingly unconsciously give them Slavonic form and garb. What does this mean? It seems, nothing more than the most intimate and natural kinship of the Russian language with Slavonic and vice versa; the latter, one may say, intertwining not so much with our national language as with the spirit of the people itself. To completely ban all Slavonicisms would mean to impoverish the national tongue, to deny its richest and most vital element, to deprive many objects and ideas of perhaps their best or at least necessary development and expression. (Amfiteatrov, II, § 277, 132-3)

Accepting in principle a literary language oriented on conversational speech, Amfiteatrov immediately asserts that the Russian (spoken) language proper lacks the means to express abstract ideas or elevated stylistics. These of necessity Russian takes from Slavonic; it follows that purism that bases itself on ridding Russian of Slavonicisms is basically unsound, and is all the more inapplicable to religious literature.

It is significant that in his discussion of linguistic purity, Amvrosii Serebrennikov (like others at the time) had in mind the language of both religious and secular literature. Now the criterion for purity turns out to be different for each, and Amfiteatrov defines this divergence. He writes:

Purity of style consists in using words and expressions a) which belong to 
the national language proper, [but] b) only those which the national language considers purified. Consequently, a) not everything is fit for writing that is in the national language; b) not everything in the entire popular language, used by various social classes, is fitting; c) but only what the best and most educated writers whose works are recognized as exemplary use... Insofar as the sermon accepts ecclesiastical-Biblical language, the purity of preaching style has far broader limits than the purity of other literary works. (ibid, II, $\S 300,161-2$ )

This permissible mixing of language extends not only to lexicon but to grammatical elements as well, and produces a special understanding of grammatical correctness. Amfiteatrov writes: "Correctness of style consists in the proper observance of the language's legitimate forms, determined by etymology and syntax in particular, and by the genius of the language as a whole... Stylistic correctness in homilies, like purity, is manifested in a far broader way than in other styles, because the homily tolerates changes and combinations of Church Slavonic words" (Amfiteatrov II, § 300, 165). ${ }^{26}$

Such notions of purity also define the linguistic program of the clergy in the first half of the nineteenth century. The purist restrictions encompass the usual aggregate of rubrics. Thus the same Amfiteatrov, listing the words which impair "linguistic purity," lists "archaisms," "neologisms," "vulgarisms," and "peregrinisms"; the last term is defined as "the unnecessary use of foreign words and expressions which appear in great quantity in schools, in systems (v sistemakh), and in the conversation of people who like to make a show of their knowledge of languages" (ibid, 162-3; on still another of Amfiteatrov's original rubrics, see below). Various statements by other ecclesiastical figures on the style of religious literature also cite these rubrics. From the start of the nineteenth century purity of style acquired special semiotic significance for religious leaders ( $(I V-2.2)$, and they were therefore constantly involved in editing in order to bring the language of religious works into line with their content; an ideal of religious language was being formulated, and everything in religious writing that didn't correspond to this ideal was felt as an offense to its sacred content. In this context, it is no surprise that at the start of the century the ecclesiastical censor was charged with safeguarding "purity and elegance of style" (PSZ, XXXII, no. 25673,

26 Another view holds that the variation of grammatical forms represents unacceptable heterogeneity. Thus when editing the 1838 Slavonic translation of the Eastern patriarchs' documents concerning the establishment of the Synod, Metropolitan Filaret Drozdov noted the divergence of [infinitive] endings, sometimes ь, sometimes и"; although he thinks that "we should preserve this diversity as a feature of the time" (Filaret 1869, 53). We need to keep in mind that the variation of infinitive endings continued to exist (with certain limitations) in religious literature in the last third of the eighteenth century (§ III-3.2), so that Filaret's comments suggest the further development of purist views. 
article 360, 943 [1814]; cf. PSZ XXV, no. 18888). Although the censorship code of 1828 prohibited the censors from "carping on individual words and expressions" and also from correcting style and "an author's mistakes in the literary regard" (2nd PSZ, III, no. 1979, §§ 7, 15, 461), in the "Regulations for Ecclesiastical Censorship" "purity of style" was indicated as a necessary quality of religious "writings intended for society's use" (ibid, no. 1981, § 44, 483), and stylistic correction based on ideological considerations continued to be the censors' usual practice. Taken together, surviving materials allow us to reconstruct the purist principles that guided religious writing.

One plank in the clergy's linguistic program was the elimination of all borrowings. In the first half of the eighteenth century borrowings had been a common element of the new religious literature, in sermons first of all, as an aspect of Baroque ornamentation (§ I-2.2; cf. Vinogradov 1938, 99); the Great Russian tradition was here based on the Kievan. During the second half of the eighteenth century, the use of borrowings significantly diminished (again, first of all in sermons); in assimilating the purist principles of the "Slavenorossiiskii" language, religious writers considered borrowings an element that detracted from stylistic purity. However, insofar as the use of borrowings at this time was not as a rule connected with any sort of ideological position, and were not perceived as an element of secular culture that was improper for religious works (purism was no less typical of secular than of religious literature of the time), some religious authors continued to make rather free use of borrowings (for example, Irinei Klement'evskii and Anastasii Romanenko-Bratanovskii). ${ }^{27}$

From the start of the nineteenth century the attitude toward borrowings changed. Thus in 1809 when a translation of Massillion's sermons was sent to the ecclesiastical censor, Archimandrite Vladimir Tret'iakov, he rejected the translation on the basis of its "literary deficiencies," even though he did

27 Sukhomlinov notes such borrowings in Irinei Klement'evskii as фамилия, лабиринт, компания, резон, критиковать, and expressions like "Павел, сей атлет христианский" (Sukhomlinov, I, 240). He cites such words and expressions from Anastasii Bratanovskii's sermons as: феномен, меланхолик, рещепт, пульс твоего сердиа, театр просвещеннаго света (ibid, 254-5). For both preachers the use of borrowings is noted as the distinguishing mark of their sermons. Concerning Anastasii, Sukhomlinov suggests that the given trait "is tied to the conversational language of society of that time and with Gallicisms which purists found in the Letters of a Russian Traveler" (ibid, 254). Connecting this to Karamzin's language may be justified to some extent, although in this case the use of borrowings was necessarily superimposed onto the earlier homiletic tradition and grew out of it. The borrowings found in the sermons of the future Petersburg Metropolitan Mikhail Desnitskii in the 1790's are of the same type, for example, “в натуральном положении, на горизонте, в видимой сей натуре, сообщенная от Бога натура, краскам натуры, весьма важны суть для человека сии два пункта: родиться и умереть," etc. (Mikhail Desnitskii, V, 17, 57, 70, 133, 152, 231, 235). 
not find anything in it contrary to Orthodoxy. He indicated that, in particular, "words belonging to the church should be translated for the most part with Slavonic phrases, for the sake of the seriousness of the content and the value of the translation, but not only is this not observed, but words are used that are completely inappropriate to the church pulpit, like: актер, роль, критика..." (Kotovich 1909, 58). In the 1810's the censor Iakov Nikol'skii deleted the word серьезно from religious writings (ibid, 79; at this period the word could apparently be taken as a marker of secular speech - see Lotman and Uspenskii 1975, 286-7). At this same period such phrases as организовать конституцию, характеристика иудея, религиозныя истины, революиия мupa [to organize a constitution, description of a Jew, religious truth, world revolution] were deemed "intolerable in a religious book" (Kotovich 1909, 58). In exactly the same way at the end of the 1830's-start of the 40's the censor P. S. Delitsyn restricted the use of such words as герой, идея, система, гармония, натурализм, патриотизм, контора [hero, idea, system, harmony, naturalism, patriotism, office] (ibid, 451). In 1847 Filaret Drozdov proposed substituting the term состав речи [composition of speech] for the term контекст [context] (Filaret 1883, 19). Similar examples could be multiplied, likewise demonstrating that in the language of religious literature borrowings were clearly perceived as a proscribed element.

The struggle against neologisms, on the other hand, was hardly a discernible part of the clergy's linguistic program. In principle the very content of religious literature presented few possibilities for using neologisms; traditional themes called for using traditional linguistic material. Amfiteatrov defined neologism as "the pointless use of new-fashioned words and expressions" (Amfiteatrov, II, 162), that is, he did not forbid individual cases of word-creation, but deviation from traditional vocabulary. In essence the issue concerned the use of expressions that were typical of secular literature but unacceptable in religious works. He cited a series of such expressions whose use he condemned as contrary to homiletic style, and wrote that

For young people writing sermons for practice, there is another lapse of taste: the desire to shine by using fashionable phrases. In the sermons of young preachers we have come across both путеводную звезду and туманную даль and неземное наслаждение; in these sermons эта благодать навевает and эти духи напевают, отобразы вынаружсиваются and перль often горят, and идеи блещут высокия, and юнья силь иветут, как весна, and любовь застыввет and надежда светлеется and so on. ${ }^{28}$ Of course, all these

$\overline{28}$ guiding star; foggy distance; unearthly pleasure; this mercy is evoked; these spirits sing; reflections surface; pearls burn; loft ideas shine; young powers bloom, like spring; love grows cold; hope brightens. 
words are innocent by themselves, but we must understand their worth and place. Because of this one meets the strangest jumble in sermons; holy truths are at variance with the spirit of the preacher, the spirit is at odds with the ideas, the ideas with the words, and completely lacking is the homiletic style. (Amfiteatrov, II, §264, 104)

At the start of the nineteenth century the protest against such innovations could also extend to calques from Western languages, so characteristic of secular literature of the time. Thus in 1807 the ecclesiastical censor protested against the phrase "нравственный правитель мира" (moral ruler of the world) (Kotovich 1909, 58), and Innokentii Smirnov wrote to Prince Golitsyn in 1817 concerning Father Sokolov's A Confessor's Conversation with a Repentant Christian that "the translator didn't heed the rules of linguistic purity and correctness, which is evident among other places in the first lines of the first page in the first question, where the one repenting asks for guidance in relation to the edification of his soul. In Russian one can't say 'guidance in relation to the edification' of the soul (наставление в отношении назидания)" (Zhemakin 1885, 76).

At the start of the century the purist struggle against chancellery language was not relevant. By this time, chancellery speech, the traditional language of bureaucracy which derived from the chancellery language of Muscovite Russia had long ceased to exist as a bona fide linguistic phenomenon, and even its remnants had practically disappeared (a major role here was played by the exams that Speranskii instituted for tsarist bureaucrats). The specifics of bureaucratic language, if it even played a role in this period, were reduced to a small group of expressions and constructions (what we now call "chancellarisms"). There was no need for them in religious writing, so protests against them were practically unheard of. Amfiteatrov does not include "juridical words" among his rubrics. However, we may cite Filaret Drozdov's apparently anecdotal criticism of a certain sermon: "I am not very comforted by the proliferation of titular, chancellery, and foreign words. It seems to me that they do not convey either religious quality or linguistic simplicity" (Filaret 1877, 137).

Much more pertinent were protests against popular speech. The limits here, however, were rather indefinite, and Slavonicizing purism could label elements that had nothing to do with the language of lower social orders as "popular" merely because they had Church Slavonic correlatives (cf. § III-1.3); this also became true for the purism of religious literature. Naturally, real vulgarisms were also seen as elements that detracted from linguistic purity. Thus in 1802 the ecclesiastical censor rejected a work 
"written in the style that is usually employed in Russian folktales which the common people have told one another from the most ancient unenlightened times" (Kotovich 1909, 57). At the end of the 1830's and start of the 40's the censor P. Delitsyn forbade as "low and coarse" such words as жранье, цалую, ретко (ibid, 451). In 1854 Metropolitan Filaret sent a religious work to the censor and specifically proposed "to ask the censor to clean up certain words and word combinations, for example, to replace картошка with картофель" (Filaret, III, 309). In other cases he could note that "the word свечка is petty for a serious and austere composition" (Filaret 1877, 184) or that the word тятька was "improper for print, especially in an article which aimed to argue on the basis of dogma and the canon" (SMO, I, 451; the word had been used in a child's directly quoted speech). In 1854 the ecclesiastical censor objected against such words and phrases as: водить за нос, хлопать ушами, бабий народ, девки, плут, пьяница, мальчишка, (lead by the nose, fall on deaf ears, womanish people, gal, rogue, drunkard, urchin), etc. (see Kotovich 1909, 418).

At the same time words that did not have especially low social overtones could also provoke objections. Indeed the category of popular speech stemmed from neutral literary usage, and notions of neutrality were different in religious and secular literature: Slavonicisms were a neutral element in religious writing but were marked as specifically bookish elements in secular literature. Still, in practice the secular literary language predominated and neither the linguistic ideas of religious writers nor the language of religious writing itself were fully immune to its influence. In the given case the correlation between linguistic views and practice is contradictory. On the one hand, the desire to revitalize traditional interaction with the Orthodox congregation prompted religious writers to use a language that was comprehensible to it; in cases when that congregation included members of the social elite - and these were the cases that set the general tone - this led the clergy to attend to the secular literary language. On the other hand, the hope of returning to traditional piety was connected to the Orthodox literary tradition and its forms of expression, and this tended toward isolating the language of religious literature from the secular. In linguistic practice both trends were active; in linguistic discussions the later isolationist tendency predominated. ${ }^{29}$ This duality led to the fact that religious authors could make

$29 \quad$ Amfiteatrov plainly took cognizance of both tendencies but tried to downplay the contradiction. He wrote: "Usage of the educated language. Whether this is the living language, used in live conversation by enlightened people from the upper classes, or the literary language that exists in well written books is all the same to us because we need an educated, refined language, wherever it exists. We need it because church discourse has the closest relation to it. Despite 
use of varying viewpoints in characterizing this or that element as popular, and this conditioned a broad spectrum of applications of the given notion.

In particular, when this viewpoint was specifically religious usage, the rubric of popular speech could include practically any Russicism, juxtaposed to Slavonic equivalents. Thus for example Archimandrite Fotii Spasskii summoned Innokentii Borisov to reject the "bad and vulgar" words этот, эти and replace them with сей, сии (see Kotovich 1909, 166). In an analogous way, in his review of Biblical History for Children Filaret Drozdov wrote on January 9, 1838, that "the divine words that everyone knows and understands have been unnecessarily changed in favor of popular speech: это тело мое; это кровь моя (This is my body; this is my blood)" (Filaret, SMO, suppl.: 615; cf. Filaret 1891, 7). Hence elements that were neutral in secular literature could appear as vulgarisms in the context of religious writing, just as elements that were neutral in religious literature could appear to be archaicisms to a secular writer (e.g., Senkovskii's protests against ceŭ, оный - Senkovskii, VIII, 205f and 235f). The dominating position held by the secular literary language prevented the full implementation of the religious purist program when it came into conflict with the principles of secular purism. Religious writers quite often, and apparently unintentionally, used the pronouns этот, эти as a neutral element, thus assimilating the predominant secular usage. Toward the end of the 1850's Metropolitan Filaret himself came to a certain compromise. Having received a Russian translation of the Gospel According to Mark, he wrote to Mmetropolitan Grigorii Postnikov on September 9, 1859, that "Just as you do not oppose the word ceй, so I do not oppose the word этот. But it seems to me that it is better to use the former where you are indicating an object of importance, or where the tone of the speech itself approaches the Slavonic" (Filaret 1877, 181). Obviously, at this period сей, сии continued to be felt as neutral for religious literature but the "popular" nature of the Russicisms этот, эти ceased to be associated with elements of popular speech that were specific to lower social strata. Filaret's normalizing suggestion did not consist in getting rid of one of the variants but in their stylistic differentiation. In this way a three-

its separate situation, strictly limited by its special content and aim, homiletic literature, however, is not so isolated and self-contained that it is completely split off from the general human word. On the contrary, as a literary work, created according to the general laws of the educated - artificial word, it is a living branch of universal literature. [...] Hence the laws of the general word are also the laws of the homiletic word; the general characteristics of educated style are also the characteristics of church-homiletic style; and the particular features of this style, stemming from the use of Biblical, church and popular language, should be judged against the general law of stylistics, and find verification in it" (Amfiteatrov, II, § 296, $154-5)$. 
part division of lexicon was established, into neutral elements (including Slavonicisms); "popular" ones, from the specifically religious point of view (but neutral for the secular language); and elements that were "popular" from any point of view. This three-way division is very clearly presented in Metropolitan Filaret's stylistic remarks on the Russian translation of the works of Basil the Great: "Пока is a pure word; покуда is more popular, if you will; покудова is a barbaric word, improperly used instead of the first two by people who do not understand linguistic analogy" (Filaret 1891, 8). If words of the last type are completely excluded, the choice between the first two lexical registers is determined by the stylistic context.

However, this compromise wasn't attained immediately and during the course of the entire first half of the nineteenth century protests could be sounded against the use of neutral Russian elements (from the secular point of view), and at times Russicisms were even replaced by Slavonicisms. Thus in the 1810's the censor Iakov Nikol'skii replaced как bу поелику, берлогу with логовище (see Kotovich 1909, 79); similarly, he could replace relative subordinate clauses by participial phrases (ibid). In 1851 the ecclesiastical censor rejected the booklet Conversations with a Sick Peasant, arguing in particular that "the simplicity of the language of these conversations in many places goes beyond the bounds of propriety which the subjects of Christian edification demand because of their importance," and further, that "everywhere in the address to the sick man who is being admonished words of heartfelt tenderness are used for which lofty and holy Christian love has no need to express itself-words like мой мильй, мой сердечный, дружечек, голубчик (my dear, my heart, little friend, little dove)" (ibid 419). In this context Metropolitan Filaret's philippic against popular elements, contained in a letter of Dec. 30, 1850, to Bishop Aleksei, is noteworthy. Filaret, reviewing the Russian translation of Lestvitsa (Spiritual Ladder), cited the expression начинать с Бога (to start from God) as inaccurate, suggesting начинать от Бога as the only correct way to say it. Generally speaking both expressions conformed to the norm of the secular language of the time, but Filaret insists that only the latter is acceptable (apparently based on actual Church Slavonic usage). Further, Filaret exclaims, "Why did the translator say it differently? There is no other apparent reason other than in his opinion this is the way the people speak, that is, the illiterate ones. Is it really necessary that this idolatry before the people, which is also destructive in other areas, make its way into religious literature?" (Filaret 1883, 77-8).

The interpretation of "popular language" that Amfiteatrov proposes is also quite characteristic. He insists that the preacher speak in a language his listeners understand, and this determines his positive view of popular speech 
(Amfiteatrov, II, § 292, 149-50). His views also reflect a romanticizing of folk language which he believes has preserved the ancient original quality of the language and expresses the national spirit. He asserts that on the basis of the popular tongue "one may describe the genius of the language, frequently lost in books and in the modern living speech of educated society. In it are safeguarded the true features of the national character (narodnost'), while the language of the upper classes may be full of what is borrowed and alien" (II, 148). All the more striking is the set of elements that Amfiteatrov thinks may be taken from popular speech for use in sermons. He writes:

The plebian has his own terminology, sometimes better than the learned man's; he has his own grammatical and rhetorical emphasis, his own aesthetic knowledge - but knowledge from nature. Thus he says мир rather than our conferences and gatherings; общество, сходка instead of parliaments; свет instead of our visible world and nature; смута instead of revolution; and so on. His кровь моя, свет мой are expressions of kinship and friendship; время дорогое and времена плохия, expressions of the difficulty of physical existence; согрешить и прогневить Бога - the reasons for all misfortunes, individual and collective ... For him хлеб is God's gift, a good day - день Божий, a coffin - домовина, domestic animals - животы, something's purpose its наряд, and so on. (Amfiteatrov, II, 151)

Elements that mostly have no particular popular coloring are presented here as specific examples of the "popular language." For most of them, their "narodnost" " boils down to an indefinite thematic primitivism and is not connected to any identification with dialect, whether local or social. ${ }^{30}$ In relation to explicit popular elements, despite all of his declarations, Amfiteatrov holds to the purism that was typical of the clergy. He makes the special reservation that "while accepting that which in the popular language is good by itself and generally suitable, a church sermon should not fall into unrestrained vulgarism and sink to the tenor of the street; it shouldn't use low and coarse words; it shouldn't turn into village sayings... In a word, it should not clothe its serious ideas that demand a serious tone and speech in plebian witticisms (pribautki)..." (Amfiteatrov, II, § 294, 153).

Amfiteatrov's real attitude toward popular speech is revealed with particular clarity in his orthoepic recommendations. He writes that the laws of pronunciation "may be based a) on church etiquette (prilichie); b) on public taste; c) on the custom of the listeners being addressed" (ibid, 242). These

\footnotetext{
30 Even the word домвина that Amfiteatrov cites in the meaning "coffin" (according to Dal', "regional" [Dal', I, 466], and домовище, "popular" in the SAR [II, col. 727]), could be used in the literary language of the eighteenth and early nineteenth century and not be seen as a popular form (see Sorokin 1949, 108-9).
} 
correspond to bookish pronunciation, standard (Moscow) pronunciation, and dialectical pronunciation, and may be related, respectively, to the norm of religious literature, that of the secular literary language, and popular speech. This correlation reveals that the religious norm occupies the basic, neutral position, elements of secular literary pronunciation are allowed with significant restrictions, and dialectical speech is completely disallowed. It is indicative that from the perspective of religious literature secular pronunciation is not treated as neutral, but as popular, low, although permissible within certain limits. Indeed, concerning bookish (liturgical) pronunciation Amfiteatrov writes:

Basing oneself on church etiquette one may pronounce every letter and word of a sermon as they are written and printed. On the one hand, such pronunciation conveys importance to a church sermon; on the other it is less dangerous for the preacher himself... A particularly bookish pronunciation is required in glorifications, prayers, the divine names and all expressions which enter the sermon from the ecclesiastic-Biblical language. This kind of pronunciation that we sometimes hear from young preachers is completely unsuitable: ' $B a$ имя-тиа, Атиза, и Сына и святова Духа, Гасподь Ісус - крястился; все упование мае; ито ми подабаить тварити; изведём слезы из очесь' - and a multitude of similar expressions. Only one drawback of bookish pronunciation, it distances the sermon from a simple friendly conversation, and thereby violates naturalness, and makes it very clear that the sermon is a [written] composition. Not a major drawback. (Amfiteatrov, II, 242; on the traditions of church pronunciation, see Uspenskii 1968; Uspenskii 1971). ${ }^{31}$

On Moscow pronunciation, Amfiteatrov writes: "Basing oneself on popular taste, one may use that dialect (vygovor) in a sermon that is recognized among other dialects as predominant and considered the best and most noble. Let us say, for ex., that for us the main and best pronunciation is the Muscovite and of the Moscow area, according to Grech's grammar... This is the pronunciation that the preacher should study; but even here ecclesiastical-Biblical words and phrases must be pronounced in the bookish way" (ibid, 242-3). ${ }^{32}$ The non-neutral status of Moscovite vis à vis bookish pronunciation is clear from the fact that a sermon may be completely

31 Note that the word for "sermon" here, беседa, itself also means "conversation." (Translator's note)

32 Amfitreatrov adds: "Let us not defend Moscow pronunciation simply because it is Muscovite, if everywhere we will start, for example, to change the final 2 to $x$ (рох спасении, блах Бог наш, расторх узы, мох каяться), unaccented о to а (слава Писания instead of слова, пакайся), $n$ into б (гроп, pan, слап, instead of гроб, раб, слаб), $ч$ before $н$ into $и$ (скушно, мрашно, тошно), г into к (друк, снек, порок instead of порог, etc.)" (Amfitreatrov, II, 242-3). 
read according to the bookish norm but not according to that of Moscow; everything that is explicitly connected to the church tradition requires the traditional church orthoepy. Lastly, dialectical pronunciation is considered incommensurate with the lofty content of the sermon (ibid, 243). Thus if in regard to vocabulary and phraseology Amfiteatrov could proceed from the perspectives of both the religious and secular literary languages, in regard to phonetics the religious norm clearly prevailed. For other representatives of religious literature this strict approach could naturally extend to all other linguistic levels.

Thus for religious literature Slavonicisms functioned as a neutral element. This also determined the clergy's attitude toward archaisms. Archaisms as a stylistic category that defined the norms of secular linguistic usage did not exist for the religious tradition. True, Amfiteatrov lists archaisms among those elements that mar the purity of the language, defining the category as "the unnecessary use of obsolete words which have gone out of use and which do not have any right to rehabilitation" (Amfiteatrov, II, 162). The examples he cites, however, demonstrate that archaicisms are not presented as objects for genuine purist protest but rather as examples of a traditional rubric of the accepted stylistic theory (as they had been earlier for Lomonosov and his followers, § III-1.3, § III-3.2). In fact, Amfiteatrov cites words like: мща, краковат, кльтуки, скута, имство, неоплазнство, смерд - words which no one (with very rare exceptions) ever employed, so there was no need to warn against their use. Notably, among the numerous stylistic criticisms contained in the ecclesiastical censorship's records and in the correspondence of individual clergymen, attacks on the use of archaisms seem to be completely absent. ${ }^{33}$

33 A seeming exception is Filaret's remark concerning the corrections he made in a translation of a certain patristic work. He writes; "I wanted to combine the Slavonic (slovenskii) aspect of the language with clarity, and therefore I sometimes changed the word order and used not very many new words instead of more ancient ones [that were] obscure or ambiguous to today's understanding" (Filaret, II, 273). The issue here is obviously not about archaisms in a Russian but a Slavonic text, and about words that had become completely incomprehensible (archaic), i.e., it had to do with modernizing Church Slavonic, which was a rather traditional task (§ I-2.1). In the same way, Slavonic translations from Greek done before the seventeenth century could be seen as archaic. Here the notion of archaism could extend to individual lexical elements as well as syntactic constructions which deviated from the usual and emulated the Greek original. In this context Metropolitan Filaret's response to a panegyric speech by Epifanii (Filaret, III, 164-5) and especially his juxtaposition of two chapters of Maksim Ispovednik's "On Love" that was submitted by Amfiteatrov (Amfiteatrov, II, § 282, $137 \mathrm{f}$ ) is typical. This was the same understanding of archaisms in old Slavonic translations that resulted in the correction of liturgical texts in the second half of the nineteenth and early twentieth centuries (see Sove 1970; Pletneva 1994), which resulted in "the replacement of 
From the point of view of the secular language, the religious attitude toward archaisms was clearly positive. Amfiteatrov not only did not limit the use of usual Church Slavonic expressions and forms but even permitted the introduction (in Church Slavonic texts) of Slavonic elements that had gone out of use. Speaking about making use in sermons of "ancient translations" whose language "time has made not fully intelligible, and in some places completely obscure," Amfiteatrov foresaw "the selection of noteworthy words and expressions from old translations [and their] renewal and introduction into the modern living language" (ibid, II, § 281, 137). In general, the preacher could resort to "resurrecting forgotten words and expressions, renewal of worn out ones, [and] introducing into living speech those that have died out over time," although "the number of words that have an incontestable right to regeneration is in general very small" (ibid, II, $\S$ $285,139)$. Clearly, this sort of recommendation turns prohibitions against using archaisms into empty declarations, a concession to traditional stylistic notions.

And so, even though the rubrics of religious purism coincided with those of secular literature, their content was quite different. That is how the matter stood with popular speech: if for secular literature popular speech comprised elements that were specific to the language of uneducated social groups, for religious purism this rubric could just as easily be applied to Russicisms which were neutral for the secular tradition. The rubric of archaisms was interpreted in similarly different ways: while for secular purism this rubric primarily consisted of Slavonicisms, for the religious tradition it had little practical importance. Hence the notion of linguistic purity for the religious tradition - as opposed to the secular - was directly dependent on the fact that religious literature assimilated both Russicisms and Slavonicisms as equally organic elements. Linguistic purity was gauged by two things: the measure of Russian and of Church Slavonic. In the place where "Russian" purism coincided with "Slavonic" purism, purist tendencies increased, and this made for a heightened sensitivity toward borrowings, neologisms, and elements of popular speech. On the other hand, where these two tendencies did not coincide, the very conception of purity changed, so that neutral Russicisms (from a socio-linguistic perspective, those in general use) could be defined as popular speech, while archaisms became exotic rarities that had no relation to actual usage.

antiquated Slavonic words [that were] incomprehensible at the present time or had [assumed] a different meaning" (in the formulation of the Bishop of Ekaterinoslav, Avgustin Gulianitskii - Sove 1970, 39). 
Understandably, the purist tendencies of secular literature which restricted the use of Slavonicisms were unacceptable for religious literature, so that as a result religious purism became clearly opposed to the secular variant. ${ }^{34}$

\subsection{The Attitude Toward the Linguistic Sign}

The opposition between secular and religious purism is not reducible to their different interpretations of linguistic and stylistic rubrics. Their very conception of purism, its ideological foundation, was fundamentally dissimilar. Secular purism was primarily a stylistic notion, unquestionably connected to a certain aesthetic position, but only defining a norm of good taste and not a correct worldview. Religious purism was conceived primarily in religious terms, and deviation from the norm was understood not only as stylistic wrongdoing but as a manifestation of impiety. In a special note of 1862 Filaret Drozdov posed the question, "Would it not be beneficial if the leading member of the Most Holy Synod secretly reminded the diocesan authorities and through them their subordinates that church sermons should make pure teaching universally comprehensible, but in a correct and pure language, and not depicting shameful things in ugly language..."? (Filaret, SMO, V, 216 - my italics, V. Z.). Thus the issue of linguistic purity was directly tied to the purity of faith and the observation of piety. Introducing "impure" language brings profane elements into a sacred context, i.e., a kind of blasphemy. Religious purism becomes a doctrine of linguistic piety.

34 It is notable that for Amfiteatrov purism was just as harmful for "linguistic purity" as was "excessive impurity" (Amfiteatrov, II, 162). Presumably he has the purist tendencies of secular literature in mind when he writes that "ruthless purity strips away the language and threatens it with extreme impoverishment; language always loses from it. Exiling old words from the language without rights, opposing the introduction of new ones, driving out the foreign, scorning its own - popular and regional, calling Slavonic un-Russian - what is left of the language? Undoubtedly, what is left is pure, but of such a character that you won't be able to clothe many ideas in it, and even so they will all seem stunted and forced into too narrow dress" (ibid, § 302, 163-4). These anti-purist sentiments closely recall Fénélon's letter to the French Academy which may even be the direct source of this passage. However, in contrast to the stylistic controversy within a single literature (between Fénélon and the French purists), here we have conflict between secular and religious literature. That Amfiteatrov is polemicizing precisely with the secular literary (aristocratic) tradition is suggested by his reference to those who call "Slavonic un-Russian." This was characteristic of the capital nobility in the eighteenth century (see Sumarokov 1748, 7; and § III-3.1 above), and Amfiteatrov may have this tradition in mind. 
From this point of view the language of secular literature is thought of as profane, opposed to the sacred tongue of religious literature, and this applies to the purity of the secular language as well. Insofar as this language assimilates as pure those linguistic elements that the religious language rejects (and rejects as impure and profaning sacred content - as we saw above in the case of borrowings, neologisms, and elements of popular speech), the secular language in its entirely begins to be perceived as impure, and consequently defiling the sacred content it may try to express. If some particular element, whatever its origin, is perceived as the specific property of the secular language, then on this basis it turns out to be impure from the point of view of religious purism.

This perception explains the fact that among the usual purist rubrics cited by Amfiteatrov, one appears that is not represented in any other stylistic classifications, and that is "romanticism" (романтизм). This is defined as "the senseless use of words and expressions borrowed from romance (romanicheskii) ${ }^{35}$ and fairy-tale (skazochnyi) literature and the like" (Amfiteatrov, II, 162). A stylistic theory here acquires not stylistic but religious and social significance, as any use of language without religious sanction is declared to be contamination. The independence of religious literature's linguistic norm is thus elevated into a principle. The purity of the language of religious literature is sanctified by the purity of faith, while the stylistic principles of secular literature are based on criteria that are wholly profane; they are therefore inapplicable to religious literature and from its perspective lead to impure word-use.

In connection with this perception, Slavonicisms are credited with a sacred quality and Russicisms defined as correspondingly profane, and the substitution of profane for sacred elements in a sacred context appears as blasphemy. This view is explicitly formulated by Amfiteatrov:

A church sermon is the reproduction of the Gospel; therefore not only must the main Biblical ideas be the primary basis for the sermon but Biblical words must also serve as the primary basis for the preacher's language. Such words are indeed met in any devout sermon; the homily assimilated them long ago, made them its substance. It has become used to employ these words constantly: благодать, крест, искупление, грех and грехопадение, возрождение оr пакибытие, самоотвержение, похоть плоти, душевный and внемний человек, внутренний and духовный, таинство, единение, ${ }^{36}$ in general, words

\footnotetext{
35 Romanicheskii" may refer to Romanticism as well as to novels and romances (both "romany" in Russian). (Translator's note)

36 grace, cross, atonement, sin, the Fall, rebirth, renewal, self-abnegation, fleshly lust, person of the spirit and external person, sacrament, unity.
} 
of dogmatic and practical content. According to the demands of its pious taste, it says: жезл, гортань, уста, мечь, благолепие, стопа and пята, риза and облачение, завеса and покров, ${ }^{37}$ - in general, words relating to religious aesthetics. These and similar words must by no means be translated or replaced by others, but be explained to people if they are unclear; for to replace them or translate them would mean distorting the language and committing sacrilege. What would result if we, for example, imitating the secular language, took it into our minds to replace the holy word благодать [grace] with secular graces, charities, charms? What kind of language would it be if instead of Госnодb Иисус [Lord Jesus] we began to say господин [master], instead of владыка [sovereign] we said боярин [boyar], instead of ax братие - ах братць, instead of самоумерщвление -самоубийство, instead of крещение - купание, instead of таинство - секрет, instead чудо - диковина, instead of песнь, песненныци - песня, песенный if we replaced гортань with горло or глотка, жезл with палищяа, мечь with шиага and so on? (Amfiteatrov, II, § 270, 121-2; italics added)

The task of separating the secular and religious languages thus became central. At the same time as the struggle was taking place in secular literature for bringing the literary language closer to the spoken and for getting rid of Slavonicisms that had Russian correlatives, the opposite was going on in religious literature - an effort to minimize Russicisms and to assimilate Slavonicisms as an organic means of expressing holy content. Understood in religious terms, this effort was seen as separating the sacred from the profane, as a defense of confessional purity.

The special religiously motivated character of the religious language was felt as a literary fact, about which we have the testimony of not only church figures but of secular literary ones as well. Osip Senkovskii, insisting that we have "completely cut ourselves off from Slavonicizing (slavenshchizna)" (Senkovskii, VIII, 225), and, like the Karamzinists, seeing the model of literary speech "in conversation with decent, educated men in the presence of sweet, educated ladies" (ibid, 220), limits his program's demands to secular literature. Rejecting the existence of the "lofty style" (i.e., a special bookish language), at the same time he makes an exception for "the style of church oratory" whose special qualities are defined, in particular, by its connection to the Church Slavonic literary tradition. On religious oratory he writes: "This is another matter! There both the language and its forms are completely different from usual literature. Religious oratory is meant for other, higher goals, follows other rules, among which one of the most important is tradition (predanie)" (ibid, 246).

37 staff, larynx, lips, sword, splendor, foot; heel, chasuble, and vestments, screen, veil. 
The separation of secular and religious literary languages is thus taken as a given, and it is indicative that Senkovskii can put his linguistic program into the mouth of a priest. In the "Letter of Landowners from Tver" one voice is that of the enlightened parson, Father Paisii. When he is told that "Baron Brambeus [Senkovskii's pen-name]... wants to annul the friendship between the Russian and Slavonic word, to assert the independence of the Russian language and put a boundary between them, so that they will no longer be mixed," he responds:

That should have been done long ago! Ne misceantur sacra profanes! Do not confuse the sacred and the profane! I have always been of the opinion that the Slavonic language must remain, like tradition, in our Orthodox church and serve the needs of the faith exclusively... I have always found it extremely inappropriate and incongruous when our gentlemen poets sometimes use the honored forms of this language for things completely [un]worthy of its grandeur, for singing the praises of дев младых, волос златых (young maidens, golden hair) and the like. I do not mention the incongruity of scattering words in another language and completely other form in a Russian story; this is pure macaronism, the height of bad taste, the absence of a feeling for the elegance of our native tongue (ibid, 222-3; cf. Zhivov 1984a, 375-6).

It is no less remarkable that Father Paisii places the blame for this mixing of Russian and Church Slavonic in the Russian literary language on Lomonosov. "If Lomonosov," he says, "had had the fortunate idea of clearly separating the two languages... by the present day the Russian language would already have been established on firm foundations... [and] would already be independent" (Senkovskii, III, 223-4).

This kind of formulation was precisely echoed by actual representatives of religious literature. Metropolitan Filaret Drozdov, for example, could compare mixing Slavonic and Russian to confusing "the pure and the dirty and the heavenly with the satanic" (Filaret 1891, 8). He gave the religious censor a harsh reprimand because he permitted the "poem молитва при кресте in which арии and хоры follow under this title..." "The censor's theological outlook and religious-ethical sense," wrote Filaret, "should have made him immediately feel the incongruity between the title a prayer at the cross and the arias and choruses that follow, that belong to the theater" (Filaret, SMO, III, 506-8). Filaret found the question of this incongruity so important that he wrote about it to the Ober-Procuror of the Synod Count Protasov (SMO, dop., 329), to the archimandrite of the TrinitySergius Lavra Antonii (Filaret, II, 206-7), and to the rector of the Moscow Spiritual Academy, Archimandrite Aleksii (Filaret 1883, 114; cf. Chistovich 1894, 357). The issue was very clearly about words; if, for example, in place of арии и хоры stood единогласныя и многогласныя песнопения there 
would have been no objections. The combining of "sacred" and "worldly" words was thus seen as blasphemy.

This type of understanding presumes a special perception of the linguistic sign that is not characteristic of the ordinary approach to language and that of representatives of secular literature. If in secular thought a linguistic sign is perceived as a convention, the given attitude to language is precisely based on non-conventional thinking (for a typology of perceptions, see Lotman and Uspenskii 1973). In European linguistic thought the perception of language as a convention became firmly established by the Cartesian tradition (see, for example, Lamy's formulation, § III-2.3). From here it was assimilated by eighteenth-century Russian writers, including religious ones. Thus in M. M. Speranskii's Rules of Advanced Oratory we read:

And what are words? Arbitrary signs of thought. But signs, considering them in their entire scope, have only one merit, the merit of accurate expression; and therefore words, as types of signs, can only have this one excellence, to accurately arouse in our mind the ideas that they are meant to signify... Let us repeat again: words are arbitrary signs of thought. Consequently they cannot signify more than we command them to, only as much as the general agreement of minds that has formed the language allows. Once this agreement has been settled, no one can change it; only usage... may from time to time make little, gradual, and individual, hardly noticeable alterations. (Speranskii $1844,160-1)$

This attitude toward the sign became part of the nineteenth-century secular tradition, and in particular lay at the heart of the Karamzinist notion of the changeability of language as a necessary and legitimate process (cf. Uspenskii 1985, 21-2). Understandably, this kind of conception leaves not only no room for the notion of "holy" words, but none in general for any kind of "sacred" sign.

Such an approach, however, could not be consistently applied to the attempt to restore the Orthodox tradition, in whatever form it took. Indeed, in this tradition a whole series of signs were ascribed unconditional holiness, the opposite of the arbitrary (for example, crosses and icons). It was therefore natural that everything that concerned the sacred sphere in any way would be conceptualized in a similar way. The perception of the holiness of all objects and actions connected with Orthodox cult was known in old Russia (socalled "obriadoverie," "faith in rites"), and with certain modifications this was revived in the first half of the nineteenth century. Metropolitan Filaret Drozdov made the connection very clearly: "The law forbids depicting holy objects on household dishware. This particular rule has a more general one as its basis: do not confuse holy objects with worldly ones so as not to offend 
against piety and toward what is sacred (for example, at a current exhibit in Moscow there is an embossed [church] garment on an altar, on which they've put a samovar, while next to a [liturgical] chalice they have placed a sink with cupids on it)" (Filaret, SMO, V, 708). Over the course of his entire life Filaret insisted on the impermissibility of mixing the sacred and profane, as did a series of other church leaders. The clergy held that the state, which declared itself to be Orthodox and derived many benefits from this, should not allow objects of piety to become part of everyday cultural life, which generally speaking was typical of any secularizing culture. It is understandable that the state was not able to stop this process, so the clergy's insistent demands took on the nature of a hopeless struggle with external signs of secularization, at the same time as it lacked the means to engage with the process of inner secularization. On January 10, 1833, Filaret wrote to the Ober-procuror of the Synod S. D. Nechaev: "It must be ordered immediately that a procession of the cross not take place in a theater. But should we even speak about the vision of [the last] judgment, I don't know. What will happen to an age that doesn't understand how absurd it is miscere sacra profanes, and finds beauty where they put gold next to filth, and flowers beside dung? Say it's not so, they'll get angry and the absurdities will only multiply" (Filaret 1895, 96). Given this attitude, it was enough for some particular elements of the religious language to deviate from the secular usage for them to be perceived as sacred, and after this for the nonconventional view of signs to extend to them as well.

Nowhere perhaps was this approach to language as evident as in its attitude towards the alphabet. As we have seen ( $\S \mathrm{I}-1.1)$, Peter's reform of the alphabet reflected all of the basic aspects of Petrine linguistic policy, signifying as it did the graphic opposition between secular and religious culture. Later, however, the contrast in alphabets was no longer correlated to a cultural opposition or to the juxtaposition of sacred and profane, and took on primarily socio-cultural significance. At least during the first two thirds of the eighteenth century elementary language learning preserved the traditional pattern, that is, it consisted in studying the Slavonic primer, prayer book and Psalter (see § 0-2), to which might be added Feofan Prokopovich's Russian Catechism (Pervoe uchenie otrokom) (on the significance of this text, see $\S$ $\mathrm{I}-2.1)$; attempts to introduce books in the civil script into primary education were not successful. ${ }^{38}$ Because of this the ability to read civil script was

38 On attempts to do this in the Ural mining schools under V. N. Tatishchev's supervision see Guzner 1980, 67-72; Nechaev 1956. As Gary Marker rightly notes (1994, 23), Max Okenfuss's suggestion $(1980,53-6)$ that this was due to the insufficient press run of Iunosti chestnoe 
connected with intermediate and not primary education, or with the transition to it (Marker 1994, 14), and was therefore accessible only to the social elite. In the last third of the eighteenth century there were attempts to reorient primary education onto the civil alphabet. Thus in the general plan for the Foundling Hospital (Vospitatel'nyi dom) (1763 and 1767), I. I. Betskoi proposed beginning with printed primers "in the language used today... which we use naturally" (Zhitetskii 1903, 44), ${ }^{39}$ but there were apparently no appreciable results until the early nineteenth century.

These socio-cultural considerations led to a situation in which the choice of script was tied not so much with content as with the audience for the edition. A series of publications intended for universal consumption could be issued in parallel, in both church and civil scripts. This was the case with two editions of Platon Levshin's Orthodox Doctrine that appeared in 1765 (Platon Levshin 1765), printed simultaneously in church and civil scripts. In the 1740's sermons were printed in civil script if they weren't sent to Moscow for publication in the Synodal typography; a series of them appeared in parallel editions. This was the case with Gedeon Krinovskii's sermons that came out at the end of Elizabeth's reign (§ III-3.1). Later theological works could also be published in civil script, apparently intended for the spiritual enlightenment of secular readers. In the post-Petrine period, however, secular literature was not published in the church script (cf. Marker 1985, 61-3). The Synodal typography was run by the church authorities and supported their activities, which naturally had little to do with publishing novels and the like. However, as late as 1817 Arakcheev could ask the OberProkuror of the Synod Prince A. N. Golitsyn to have the Statute on Military Settlements printed in church type (see Kotovich 1909, 294). ${ }^{40}$ The absence of a clear connection between publications' content and script did not create

zertsalo (Honest Mirror of Youth), which was to serve as a textbook for the civil script, is groundless. The reason was devotion to traditional methods of teaching, and possibly also the insufficient readiness of teachers to deal with innovations.

39 Similarly, in Iankovich de Mirievo's Rukovodstvo uchiteliam pervogo i vtorogo klassa (Guide to Teachers of First and Second Grade), published in 1783, he wrote: "In Russian books they use two prints, church and civil. The knowledge of both of these is equally necessary to everyone, and therefore one should learn both together. But since when studying one should always start with what is easiest, and civil print has both the advantages of being easier for reading by syllable (v skladakh) and having a simpler and shorter alphabet, one should always start with the civil script" (Tolstoi 1886, 54; cf. Zhiteiskii 1903, 45).

40 The motive for this was evidently the desire to acquaint the largest number of people possible with this work, including peasants. Peasants usually received basic official information from rural clergymen who read official documents aloud. However, even at the end of the eighteenth century "the Synod had determined that most parish priests could not read the civil script and that they were consequently unable to perform their mandated duties" (Marker 1994, 12). 
a predisposition to the semiotic opposition of scripts. In the context of the later eighteenth century cultural synthesis, both scripts were seen as part of a single culture, so that kirillitsa (the church alphabet) was not seen as the property of the clergy, and its use was not under its strict control. In particular, at the end of the eighteenth century, church script could be freely used in titles or for additional numeration in books of completely secular content (for example, M. Popov's translation of Jerusalem Delivered — Tass 1772).

With changes in the nature of primary education, secular society gradually grew unaccustomed to church type, and reading books printed in it became increasingly difficult. In time books in kirillitsa came to be perceived as meant for a religious rather than secular audience. Characteristically, in 1803, in the midst of a bitter struggle with the higher clergy, the Ober-Procurator of the Synod A. A. Iakovlev decided to reprint the Spiritual Regulation, and to reprint it in the civil script, so as to make it universally accessible and to make perfectly clear the limits which Peter I had put on the church's power. Iakovlev wrote: "I realized that the ignorance of our citizens concerning the precise limits of the clergy's power that are so clearly set forth in the Spiritual Regulation have contributed to no little injustice and to various abuses, and therefore, to spread knowledge of this book among the people, which was heretofore printed in Church Slavonic and in church letters... I proposed that the Synod order the Spiritual Regulation be reprinted in civil script-and anyone can easily imagine how little they liked this little idea" (Iakovlev 1915, 21; cf. Chistovich 1894, 7). The church script thus became limited to use in religious education and writing. ${ }^{41}$ As a result the juxtaposition of typefaces again came to be correlated with the opposition between the sacred and profane and the clergy began to complain about violations of this relationship. In 1843, for example, the Synod forbade the printing of the church service commemorating St. Arsenii Konevskii in civil type, basing its decision on the argument that "all services to the holy saints have been printed, and are printed in church letters" (Kotovich 1909, 216; cf. Sove 1970, 36-7). And in 1830, when M. N. Zagoskin's novel Iurii Miloslavskii

$41 \quad$ In the early nineteenth century the audience for books printed in church script (primers) could also clearly be seen as the lowest social strata whose education was limited to learning the catechism. In this period, teaching them the civic script, which gave entry to secular culture, could be seen as a sign of freethinking. Thus in the case of Staff-Captain Mit'kov, whose copy of Pushkin's "Gavriliada" was confiscated in 1828, the order he gave to his estate manager in which he "allowed him to teach peasant children to read, but in the civic rather than church script" drew special interest (Perepiska 1911, 200). For both Staff-Captain Mit'kov and his investigators the choice of primer was associated with the opposition of secular and religious culture. 
was being published, and had its section headings ("part one," "part two," etc.) set in church script, the Synod declared: "Have it known to the necessary parties that the Most Holy Synod considers it improper to use church typewhich exists for liturgical books and those of religious content alone-in a novel or other secular books" (Kotovich 1909, 294; cf. Lotman, Tolstoi, Uspenskii 1981, 315). In this way the completely arbitrary signs of the civil and church alphabets were again semioticized and served to differentiate the two cultural spheres.

Thus the clergy returned to old views of the bookish language as one that was sacred by its very nature, as a language that was itself an image of orthodoxy, one that teaches the correct faith and which unconditionally (and untranslatably) conveys its content. It was just this way that in the seventeenth and early eighteenth century Russian bookmen could perceive Church Slavonic in its opposition to the non-bookish language (see Uspenskii 1984). Revived in the nineteenth century, this view was applicable both to Church Slavonic and to Slavonicized Russian (Slavenorossiiskii, which had become the literary language of the clergy); both were opposed to the profane tongue (both to the secular literary language and to the spoken language). ${ }^{42}$ In these conditions the notion of the iconic, nonconventional nature of the sign, characteristic of pre-Petrine linguistic consciousness, was also revived. Of course, this new attitude toward the sign applied to the entire spectrum of semiotic behavior, and not only to language.

In ancient Russia the semiotization of all aspects of behavior that came into contact with the sacred sphere is usually associated with socalled "obriadoverie" ("faith in rites"), one of the characteristic features of Russian religious consciousness. In the nineteenth century externally similar phenomena have a completely different source; in any case, we should not apply the term to the majority of church leaders of the time (almost all of whom were to some degree influenced by Protestant theology, for which, understandably, the attitude toward religious rites was relativist). Emphasizing the semiotic significance of anything that came into contact with the sacral

42 If in pre-Petrine Russia Church Slavonic was perceived as a kind of "icon of Orthodoxy" (Uspenskii 1984), foreign languages (Tatar, Turkish, Latin) could be seen as expressions of various kinds of non-Orthodox impiety (Islam, Catholicism). Curiously, this view finds an analogy in the cultural and linguistic views of proponents of religious purism. Thus talking about teaching in Latin, Metropolitan Filaret wrote to Filaret Gumilevskii: "I have written to you about theological lessons in Russian. And meanwhile, speaking about this here, I again met with vacillation. What can we do? People think that they are defending Orthodoxy, defending a non-Orthodox language" (Filaret 1872, 52 - letter of April 10, 1837). Latin thus turns out to be a "non-Orthodox" language; in another instance Filaret calls it "pagan and papist” (ibid, 50). 
sphere became a way of fighting against the secularization of the Russian state and society (as noted above). This explains the pedantic insistence on the sacred status of objects of piety and the charge that confusing them with those of secular culture was blasphemy.

Concerns of this kind were constantly on the mind of Russian church leaders of this period. Thus, for example, Metropolitan Filaret gave a negative evaluation of N. V. Sushkov's "The Beginning of Moscow" that was written with the most virtuous of intentions. The drama depicts the hermit Bukal, man of prayer and missionary, surrounded by the pagan ways of ancient Rus'. This situation itself offends Metropolitan Filaret, who writes: "This mixing of the true and the false, plunging a saint into worldly impurity [would be] strange to see written in a book, and I think even stranger spoken in a theater. The writer, as I understand it, had the good idea of depicting the religious origins of Moscow. But when he dressed up this main idea in the various guises of life at that time, this clothing proved, in my opinion, too worldly for the spiritual idea" (Filaret 1905, 174 - review written on January 5, 1853). In 1866 Filaret protested against the proposal to send Russian historical treasures to Paris for a universal exhibition: "Icons, church vestments and objects for the altar, as consecrated objects, are protected from [being put in] places that are inappropriate for them and from being mixed with worldly objects" (Filaret 1905, 298). Similar ideas force Filaret to constantly protest against works with religious content being included in theatrical or concert programs (see Filaret, SMO, III, 504-5; SMO, V, dop., 328-9; Filaret IV, 426-7), and he even formulates this protest as a principle of Orthodox piety. In 1855 he writes concerning a concert: "Let art lovers get angry with me if they will, but I cannot hold back my opinion that lofty subjects, the creation of the world and the last judgment, that demand reverential meditation, are demeaned and slighted when they become a musician's plaything for the amusement of the listener. The impropriety is unavoidably compounded when words are added to the music" (Filaret, SMO, IV, 48-9). ${ }^{43}$

It is indicative that the person of an archdeacon could also be included among sacred objects, alongside religious artifacts and Biblical

43 Similar protests could be made when the placement of sacred objects in a profane context was clearly unintentional; blasphemy was not seen as the result of a deliberate affront to something holy but as an objective fact due to an incorrect attitude to signs, revealing society's lack of spiritual feeling. Thus, for example, in 1858 Metropolitan Grigorii Postnikov wrote to the Petersburg governor-general protesting against pictures of fashionable Parisian dresses that appeared in the journal Son of the Fatherland that were decorated with crosses he found similar to those on sacerdotal robes [...] (Lemke 1904, 323-5), and Filaret took steps to prevent an iron factory from producing tiles with the image of a four-pointed cross (Filaret, III, 212-3). 
sayings. Thus in 1833 Filaret wrote a statement in the name of the Synod in which he criticized the improper nature of the celebrations taking place in Archangel in connection with the opening of a monument to Lomonosov. In it he described as blasphemous, in the first place, "the mixing of holy and secular, that was especially strange for the simple folk... in that the archdeacon who delivered a proclamation in church [also] read a speech at the monument," and secondly, that "in this speech the holy dictum 'This day which God created' was used inappropriately" (Filaret, SMO, dop., 581). Obviously, with such sensitivity to the mixing of sacred and profane any differences between the languages of secular and religious literature become semioticized and further motivate the desire to segregate the respective elements. Thus linguistic elements illustrate a particular case of a larger cultural and semiotic development.

\subsection{The Secularization of Slavonicisms and the Juxtaposition of Religious and Secular Traditions}

The religious conception of purism is manifested with special clarity in regard to those words which had entered the eighteenth-century literary language from Church Slavonic but had acquired new meanings, often precisely opposite from their older ones. This material demonstrates how the ideological understanding of linguistic facts leads to changes in language practices. In preserving the literary language of the late eighteenth century and making it their own, the clergy nonetheless transformed that language at those points which contradicted the idea that it represented a nonconventional expression of Orthodox culture.

The "secular" assimilation of Church Slavonic elements took place throughout the entire eighteenth century, and occurred in various ways. The process could be deliberate, as when Slavonic words with altered meanings were purposefully introduced into the literary language in order to enrich its vocabulary. The creation of this sort of semantic neologisms was acknowledged even by conflicting linguistic programs ( $\S$ IV-1.1). This process occurred with special intensity in translations, where Slavonic elements were used to express the corresponding meaning of the original. Insofar as translation was one of the main means of forming the literary language, the use of semantic calques had primary importance for the Russian literary language (on its scope one can judge by the evidence presented by G. Hüttl-Worth - 
Hüttl-Worth 1956). Conversational speech could also clearly serve as another source of semantic calques, primarily the speech of the Europeanized gentry; here calques from French gradually lost their specifically conversational character and were perceived as neutral literary usage.

These processes significantly modified the use of Church Slavonic elements in the Russian literary language in comparison to Church Slavonic. Slavonic forms could be used in a syntactic function that was unusual for them (cf. in this connection participles in phrases like блестящий оратор - Isaatchenko 1974, 255). At the same time, Slavonic vocabulary could acquire meanings not only different from the original ones but directly opposite to them, and what is more the clash of meanings created could potentially be associated with the opposition between secular and religious. This makes it possible to define this development as a process of secularizing Church Slavonic vocabulary, or, from the later religious perspective, its profanation. $^{44}$

Thus, for example, if in Church Slavonic usage мечта, мечтание, мечтательный (dream, dreaming, dreamy) signify false sensations which arise because of demonic delusion, in the process of secularization these words acquired a different meaning - of something desired, ideal, lofty; this new interpretation arose by the correlation of the Slavonic мечma with the French rêve. The lexemes cтрасть, страстный, обаяние, обаятельный, соблазнительный underwent the same kind of change under the influence of their French counterparts passion, passioné, charme, charmant, séduisant (see Vinogradov 1953, 208-9; Hüttl-Worth 1968, 14-5; Lotman 1970, 86-7). It is significant that to the extent that these innovations were assimilated by the conversational language they could become the arena in which social dialects of the nobility became differentiated from those groups of society that to one extent or another preserved traditional Orthodox culture. Hence

44 G. Hüttl-Worth $(1968,10-12)$ makes a distinction between "secularized" Church Slavonicisms whose adaptation to the Russian literary language "primarily consists in the full or partial break with the religious sphere," with insignificant semantic changes, and Church Slavonicisms which "were subject to more significant changes in the Russian literary language" (words like прелесть, восхищение, etc.). The author, however, immediately notes that "precise division" of the two groups "is almost unrealizable in practical terms" (ibid, 13). It seems as if one should speak here only of various nuances in the framework of one single process of rethinking Church Slavonic lexicon for secular use. Therefore, in my opinion it is fair to speak of semantic secularization and secularized meanings. The degree of semantic difference can hardly be used as a differentiating parameter [...] The emergence of secularized meanings (in both groups Hüttl-Worth cites) is the result of a single cultural and linguistic process of adapting traditional symbolic forms to new conditions of secularized social consciousness and everyday life. It is revealing that from the retrospective view of the mid-nineteenth century, all aspects of this process were perceived as a single phenomenon - profanation of the holy. 
we have a typical dialogue in A. N. Ostrovskii and N. Ia. Solov'ev's comedy "The Shy Girl" (Dikarka). To the question of her nanny as to where she's been, Varia answers "I am dreaming," and this answer provokes Mavra Denisovna's quick response as she interprets the word мечma in the traditional sense: "What kind of dream are you having? Dreaming is sinful, people cross themselves to ward off dreams, while you, shameless, go off at night into the garden to cultivate them" (Ostrovskii and Solov;'ev 1915, 213; act III, scene 1). This is still another aspect of socio-cultural differentiation that contradicted the universality of the new literary language (cf. § $0-6$ ).

A series of similar changes evidently originated in the conversational speech of the noble elite. It is most likely here that прелесть and прелестный began to be used in the meaning of charme and charmant, очаровательный in the meaning séduisant, обожать in the meaning of idolâtrer, трогательный in the meaning of touchant, пленительный in the meaning of captivant or the German fesselnd, and so on (see Hüttl-Worth 1956, 144-5; Hüttl-Worth 1963, 145; Hüttl-Worth 1968, 15; Lotman and Uspenskii 1975, 248-9, 296, 301-3, 307-8). From this also probably come the secularized use of such phrases as Боже мой (cf. топ Dieu) мой ангел (cf. mon ange), о, небо (cf. $o$ ciel) (Lotman and Uspenskii 1975, 249, 290). These processes are by no means unique to eighteenth-century Russian; the same kind of semantic evolution was characteristic of sixteenth and seventeenth-century French; cf. in particular Bouhours complaints that "the caprice and tyranny of usage" are profaning words that formerly only had religious meanings (Bouhours 1671, 114; he is discussing use of the word feste [i.e, fête], in a secular context).

While religious and secular literature were thought of as one, using a single literary language, this new secularized usage could freely make its way into works by religious writers without triggering any objections. Thus for example M. M. Speranskii could demand of a sermon "that its virtue be enchanting (прелестна) but simple" (Speranskii 1844, 41). He further writes that "the main aim of church speaking... is to touch (тронуть) the heart" (ibid, 13), and he clearly also uses мечтание in the neutral, secularized meaning (ibid, 168). In translating Trublet's guide to homiletics Evfimii (Evgenii) Bolkhovitinov freely used such expressions as очарование красноречия, трогать, пленять, чувствительныя и трогательныя сочинения (the charm of eloquence, to touch, to captivate, sensitive and touching compositions) (Trublet 1793, 7, 11, 29, 38). Even Metropolitan Filaret Drozdov, who later strongly insisted on the purity of the religious language, in 1813 could write o духе патриотического мечтания (about the spirit of patriotic dreaming) and could exclaim: "Send me a salutary spirit... so that in a light dreaminess (в легком мечтании) it will also carry 
me above the interminable vistas of incredible events (nad neobozrimym poprishchem neimovernykh sobytii) " (Filaret, SMO, dop., 2, 12). Similarly, in his speech at the first celebratory session of the directorate (konferentsiia) of the Petersburg Spiritual Academy on August 13, 1814, he said that "this dwelling... is not so much captivated (пленяется) by solemnity as struck by the importance of the present event" (Chistovich 1857, 233). Examples like this could easily be multiplied. ${ }^{45}$

However, by the 1810's these semantic changes began to be seen as significant from a religious perspective, ${ }^{46}$ so that any specifically secularized usage could potentially be perceived as blasphemous. At first the prohibition on such usage pertained equally to secular and religious literature, to which censorship activities at the end of the Alexandrine period testify. Surveying these activities, F. Bulgarin wrote: "What did the censor do under the influence of the mystics and their opponents? Disseminating books that were harmful for the pure faith, it only banished words and expressions that had become sanctified by time and usage. Here are a few little examples of expressions prohibited by our censorship as offending against the faith: отечественное небо, небесныий взгляд, ангельская ульбка, божественный Платон, ради Бога, ей Богу, Бог одарил его, он вечно занят был охотой (sky of the fatherland, heavenly glance, angelic smile, divine Plato, for God's sake, honest to God, God endowed him, he was eternally occupied by the hunt), and the like. All of the marked words were forbidden by our censorship, and literature, especially poetry, was completely held back" (Lemke 1904: 380).

A large number of the expressions listed by Bulgarin had entered the Russian literary language in the eighteenth century (see for example such phrases in Lomonosov as божественны науки [divine sciences] or небесныя очи [heavenly eyes] — Lomonosov, I, 147; II, 282), and in many cases they were adapted under the influence of Western European languages (cf. the French un regard céleste, un souris Angelique, le divin Virgile,

$45 \quad$ Examples from sermons by Feofilakt Rusanov may serve to characterize earlier practice, e.g.: “...двигнулся Сердобольный Монарх наш, тронутый воплем обиженных” (Feofilakt Rusanov 1807, 10); "Какое человеколюбивое сердце не пленится дружеским участием?” (Feofilakt Rusanov 1808, 12). This kind of word use is also characteristic of the Kievan preacher Archpriest Ioann Levanda: “...возвращает день, пленяющций мысли”; “Он тем сильнее пленяет очи и сердце твое"; "Как смешны пред небесным умом усилия и мечты его...” etc. (Levanda, II, 173, 215, 328). See also in Gavriil Petrov: “То, что ты рек, неоспоримо и тем прелестнее“ (Barsov, I, 14).

46 Characteristically, Metropolitan Filaret, when he later made use of this sort of word, might review their etymology, i.e., try and give them back their former, non-figurative meaning; cf. in his letter to A. N. Murav'ev of August 7, 1836: "The Christian philosophy of Abbot Beautain did not captivate (пленила) me, that is, did not force me to read to the end" (Filaret 1869, 40). 


\section{l'auteur le plus divin, pour Dieu, au nom de Dieu, etc.).}

In the eighteenth century such word combinations seemed like natural rhetorical embellishments, making use of words in their figurative meanings that oratory could not do without. In his "Speech on Oratory" of 1745 Trediakovskii wrote that "when eloquence wants to depict a certain person, a certain mind, a certain purity which is so excellent that there is none superior, she articulates with solemnity: a divine man, divine reason, angelic purity; for there is nothing more perfect than divinity, or purer than the heavenly spirits" (Trediakovskii 1745, 89). ${ }^{47}$ V. S. Podshivalov makes an analogous point: "one must however be careful not to search too far for a similarity between things if we want a metaphor to be good. One may for example call a beautiful person an angel, or gold the devil, but to call a flighty person a swallow... would be awkward" (Podshivalov 1796, 53-4); calling someone an angel is clearly not perceived as a religious issue. This norm constituted the contrasting background for early nineteenth century views.

In Bulgarin's statement cited above he connected the censors' actions with "the influence of the mystics and their opponents," that is, an actualization of the religious position unconnected with any particular ideological tendency - both the mystical and anti-mystical opinion of word use became subject to religious interpretation. As a result secularized word meanings ceased to be felt as neutral and were juxtaposed to "pious" ones and perceived as blasphemous. This process also links the consciousness of these defenders of linguistic piety to that of the seventeenth century, when metaphorical usage could be seen as unacceptable and sacrilegious in principle. In the late seventeenth and early eighteenth centuries the metaphorical tradition of the Baroque came into direct conflict with this traditional cultural-linguistic consciousness and required constant selfjustification (see Uspenskii and Zhivov 1983, 25-30).

Together with this, once the religious perception of semantic relationships became established, as noted, it spread to all other linguistic

\footnotetext{
$47 \quad$ Later Trediakovskii changed his opinion and protested against expressions like "heavenly beauty" and "eternity was revealed," basing himself precisely on religious grounds. His however was a lone voice of protest, which received no sympathy or official support. G. N. Teplov described his position as philological madness: "Not every writer finds the threat of atheism in trifling words... To his brain none of these adjectives may be used: совершенный, безконечный, безпредельный, безчисленный, безмерный, even if applied to such words as хлеб, пища, народ, вкус, etc. [...] And after such stupid sophistries he will exclaim like a madman, 'O declaration of atheism!'” (Teplov 1868, 76; for more detail see Uspenskii 1985, 166-7). In the eighteenth century Trediakovskii's position remained an individual eccentricity (in any case, from the perspective of the reigning culture), and the word usage he criticizes was seen as completely normal.
} 
elements for which such categorization was possible, independent of the historical processes that may have led to a particular word having acquired both "secular" as well as "church" meanings. In particular, this was how Slavonicisms for which the given pairing was usual (that occurred within the framework of Church Slavonic) were perceived, but which in the Russian literary language acquired (Russian) synonyms that came to replace the corresponding Slavonicisms in secular word use. This mechanism of perception is clearly evident in the episode of the censors' ban on Zhukovskii's ballad "Ivan's Eve" in 1822 (later entitled "The Fortress of Smal'gol'm"), a translation of Sir Walter Scott's "The Eve of St. John." The censors rejected the work precisely because they thought it mixed the sacred with the profane, moreover they both demanded piety of a "general semiotic" sort ${ }^{48}$ as well as linguistic piety; Zhukovskii was criticized for the secularized (and therefore sacrilegious) use of the word знаменье. Zhukovskii complained in a letter to A. N. Golitsyn of August 17, 1822, "I am not able to even imagine what Messrs the censors base their opinion on; but I have heard that among other things in the verse 'И ужасное знаменье в стол возжено!' (And a terrible sign was burned into the table!) the word знаменье scared them. Does one have to explain that the words знаменье and знак are the same thing, and that in neither is there anything blameworthy? If the censors think that the word знаменье belongs exclusively to holy objects and shouldn't express anything mundane, they are mistaken, and in order to agree with them in this case, one would have to deny one's knowledge of the Russian language" (Sukhomlinov 1865-1866, 38-9).

The history of the words знаменье and знак allow us to reconstruct the censors' reasoning. At first the two words indeed had a series of common meanings, but occurred in texts of different linguistic registers (see Sreznevskii, I, col. 988-9; SRIa, VI, 39, 42-3). In early eighteenth-century texts they could be used as synonyms (for example, in Prokopovich's works - see Kutina 1982, 33). In the Dictionary of the Russian Academy знак and знаменье are partial synonyms (SAR, III, col. 99, 105), more than that, the first meaning of the word знаменье is given precisely as "sign, signification, proof." In the eighteenth century, however, there was a differentiation in the use of these

48 In justification for the ban it was argued, in particular, that "for many readers it will seem surprising and even improper that in a Scottish folksong, in a superstitious tale about the appearance of a dead man, in his unfaithful wife's seductive conversation with him, extremely inappropriate speech is directed to the Creator, the Cross, to the great Ivan's Day; and clergymen, monks, funeral rites and a chapel are presented" (Sukhomlinov 1865-1866, 45). Zhukovskii was also informed of the demand that he "replace the rites of the Greek church, supposedly depicted in Walter Scott's ballad, with Scottish ones" (ibid, 39). 
words that corresponded to rethinking their genetic opposition (reflected in the examples cited in the Academy dictionary). The Slavonicism знаменье was primarily used to denote church phenomena, while the Russicism знак was applicable to the secular sphere; notably, the Academy dictionary of 1847 labels знаменье as "ecclesiastical" (STsRIa, II, 92). Correspondingly, applying the word знаменье to profane phenomena is perceived as using it in its secularized meaning and interpreted as blasphemous; references to past precedents were just as little convincing to linguistic consciousness of the early nineteenth century as the case of using the words "divine" and "heavenly" in the old way. This new perception forced Zhukovskii to change the disputed line, and in the final version we read "И печать роковая в столе возжжена" (And a fateful imprint was burned in the table). ${ }^{49}$

The situation changed when in 1824 A. S. Shishkov took A. N. Golitsyn's place as Minister of Education. In the new censorship code "caviling at words" was no longer to be a part of the censors" job. The new linguistic policy legitimized the use of words in their secularized meanings. In his "Second Epistle to the Censor" of 1824, Pushkin specially noted and welcomed this aspect of the new code:

\section{Когда ты разрешил по милости чудесной Заветные слова божественный, небесный, И ими назвалась (для рифмы) красота, Не оскорбляя тем уж Господа Христа!}

(Pushkin II: 367)

(When by miraculous grace you permitted the cherished words divine and heavenly, and they were used to designate beauty (for the sake of the rhyme), without insulting the Lord Christ!)

The innovations, however, only affected secular literature, although it was not left to its own devices right away and without a struggle, as the zealots of linguistic piety could make demands on secular literature of the type we have seen even after the new censorship code. Thus A. V. Nikitenko tells in his diary entry of March 16, 1834, how "Filaret [Drozdov] complained to Benkendorf about one line of Pushkin in Onegin, where in describing Moscow he has 'и стая галок на крестах' (and a flock of jackdaws on the crosses). Filaret found this to be an insult to the sacred. The censor, who was called to decide, said that 'jackdaws, as far as he knew, actually do sit on the crosses of Moscow churches, but in his opinion, the Moscow chief of

This is actually even more accurate compared to the English original: "The sable score of fingers four,/Remains on that board impressed" (Scott 1831, 446). 
police is more responsible for this than the poet or the censor.' Benkendorf politely answered Filaret that this matter was not worth the attention of such a respected spiritual figure" (Nikitenko, I, 139-40; cf. Lotman 1980, 328). Of course, Filaret's criticism was not about the jackdaws' behavior but the use of the word cross to depict an element of the landscape, i.e., in its profane, secular sense.

While the new code did not affect religious literature, secularized elements continued to be perceived as blameworthy. In this area the norm of the secular language diverged with that of the religious, as the secular was permitted word usage that in the religious context was considered blasphemous. Understandably, this intensified the clergy's view of the secular literary tongue (as opposed to the religious language) as emphatically profane and depraved. This was an additional argument for the conception of religious purism.

This norm of the religious language was explicitly articulated in Amfiteatrov's handbook. In it he demands "holiness" of the religious language and explains that this consists in

the strict choice of words and expressions which are in the highest degree appropriate to the worthiness of the proposed subject, the worthiness of the holy place and time where and when the sermon is presented, that is, worthy of God's temple and the liturgy. This appropriateness is based in part on the meaning of the words themselves, and in part on their use. Hence: a) Words may be holy in and of themselves, if they designate holy objects; consequently only use holy words for expressing holy truths. b) Words may be holy of themselves, but their use may be impious; consequently do not use holy words to designate non-holy objects, for example, do not call a person a divinity as the secular language does or say "my angel" to someone who is by no means angelic, and so on. c) Words which are extremely solemn and holy in themselves are often distorted by worldly speech and the language of fashion; consequently, use words which have been profaned by the secular language with prudence and caution. Or, in the same vein, never use such words in the same tone and meaning as fashion does. (Amfiteatrov, II, § 274, 128-9).

Later, clarifying what he means by fashionable usage, Amfiteatrov directly addresses the process by which Slavonicisms become secularized, defining this process as immoral, and secularized usage as sacrilegious: "Immorality brought many words with it into human language which in general should not be there, and did even worse, applying holy words to dishonorable things and deeds. It is well known how the fashionable language uses the words: божество, ангел, небесныя ульбки, святыня, святилище, завеса, заветный, провидение, промысл, храм, обожать, молиться, благоговеть, истаявать (divinity, angel, heavenly smiles, sacred object, 
sanctuary, veil, cherished, providence, providence. temple, adore, pray, revere, melt away), and a host of other expressions. The language of the world and of the flesh stole these words from the holy tongue, and made idolatrous use of them" (ibid, 129). Correspondingly, Amfiteatrov formulates rules which prescribe the identity of Slavonicisms in religious literature with their original meaning in Church Slavonic: "a) use Biblical words in the precise sense in which they are used in the Bible; b) do not use one and the same words in various meanings" (ibid).

A series of comments by Filaret Drozdov suggest that such rules were not purely speculative but in fact prescribed religious practice (at least its public aspect). Filaret quickly responded to what he saw as violations of the given norm. Thus in 1844 he reproached the Moscow ecclesiastic censorship committee for permitting the phrase малодушные и невежественные возгласы in a translation of Basil the Great from Works of the Church Fathers (year 4, bk. 3). In a letter to F. Golubinskii he wrote: "Возглас is a Slavonic word, and for twenty years it has not been used anywhere but in the service-book, where it designates the doxology proclaimed by the priest after the sacramental prayer. Recently a penchant for mixing the pure and the dirty and the divine with the satanic has arisen, and the holy word has sacrilegiously been applied to ridiculous exclamations and proclamations. And Father Peter [Delitsyn, member of the censorship committee], a priest himself, emulates this!" (Filaret 1891, 8). That a new secular usage of the word возглас was indeed developing at the time may be judged by its appearance in I. S. Turgenev, cf. "First we called to one another ardently; then he began to respond to our cries [возгласы ] more rarely" ("L'gov," from Notes of a Hunter). For the mid-nineteenth century this usage was common and neutral, and as such could penetrate into the speech of the clergy. ${ }^{50}$ Thus Archbishop Filaret Gumilevskii wrote to Archbishop Innokentii Borisov on May 5, 1853: "Your Excellency wrote that one must not become discouraged listening to the yelling [возгласы ] about our affairs" (Barsov, I, 143). One may conjecture that the secularized sense of the word in the meaning "exclamation" was the result of its correlation with the French exclamation, suggested in particular by the expressions возгласы удивления, возгласы радости which were calques of the French exclamation de surprise, exclamation de joie. If we suppose that the twenty-year period Filaret mentioned above was not accidental, it may be interpreted in the framework of the periodization set forth earlier, i.e., it was just at this time that secular literature was freed from

However, the dictionary of 1847 , like the Dictionary of the Russian Academy, gives the word only in its church meaning (see STsRIa, I, 144; SAR, II, col. 76). 
the censors' control over language, which allowed the unimpeded secularized use and reinterpretation of Slavonicisms. It was just this process that Filaret had in mind when he spoke of the developing taste for "mixing the pure and the dirty and the divine with the satanic."

In an analogous way Filaret objects to the use of the verb гордиться not to designate the sinful feeling of vanity but to signify a high opinion of something. Apropos of Alexander II's use of the phrase горжусь вами (I am proud of you) when addressing the troops, Filaret wrote a special confidential memorandum on December 8, 1855:

I remember how before 1812 pious-thinking people complained that the tsar's acts used only the secular language, and God's name was absent. That year demonstrated where one must seek true support and unconquerable strength, and Emperor Alexander began to speak in Christian language. Emperor Nikolai Pavlovich spoke the same language, and with power and edification especially toward the end. This is also [true of] the most pious sovereign now reigning. But all the more glaring is the discrepancy when a too worldly word unintentionally slips in. Several pious-thinking people expressed dismay that they heard from the person of the late Sovereign resting in God's bosom, and also from the person of the present one, the following phrase in praise of the troops: горжусь вами (I am proud of you). Why, they ask, did this word, so alien to him, creep into the speech of the most pious of sovereigns? God's word does not condone pride, but says that God resists the proud [Proverbsa 3: 34]. Is there some means for the editor of the tsar's thoughts to suggest that when he puts together his expressions he consider the question, are they in harmony with the pious spirit of the tsar? (Filaret, SMO, IV, 54-5; cf. the report on this note in the letter to Archimandrite Antonii of December 15, 1855 - Filaret, III, 369-70).

It is indicative that in this memo Filaret directly juxtaposes the "worldly" and "Christian" languages and connects the use of the verb гордиться in its secular meaning with the influence of the "worldly tongue." ${ }^{1}$

51 Filaret refers to 1812 as a turning point in the history of the language of state acts. As is well known, the war with Napoleon was perceived by contemporaries as a holy struggle between a righteous tsar and an apocalyptic beast. Russia appeared as the "new Israel," with Alexander I in the role of Moses and Napoleon as pharaoh. It was in this spirit that Alexander I's manifesto on the war was written, which Filaret may have in mind as the turning point. The manifesto was compiled by A. S. Shishkov, at that time state-secretary. It naturally reflected Shishkov's linguistic program, which was close to that of Filaret at least in the fact that Church Slavonic was considered the organic basis of the Russian literary language. Looking back retrospectively from the mid-nineteenth century, Shishkov's language could appear as "Christian," as opposed to the "secular" language of the Karamzinists. Characteristically, P. A. Viazemskii, who found the language of Shishkov's manifestos objectionable, was also ironic about their emphatic piety (Viazemskii, IX, 196). Thus for both Viazemskii and Filaret the notion of a "Christian" language was connected with Slavonicizing. 
Indeed in Church Slavonic гордиться only means "to laud oneself unjustly " (see Sreznevskii, I, col. 613; SRIa, IV, 82); the Dictionary of the Russian Academy also only lists this one meaning, interpreting горжусь to mean "I act haughtily, with disdain for others; I think a lot, highly of myself; I extol myself, act arrogantly" (SAR, II, col. 421). The dictionary of 1847 already includes another meaning as well — "to boast of" (хвалиться) giving as an example Я горжусь именем Русскаго (I boast [am proud] of the name Russian) (STsRIa, I, 278); it is significant that this secularized meaning has a shade of disapproval (хвалиться means to give something a high evaluation without sufficient basis). The given meaning evidently developed on the strength of the correlation between the Russian гордыı̆ and the French fier, so that гордиться чем-то enters the language as the equivalent of the French être fier de quelque chose.

In this way the expansion of secularized meanings served as one more basis for juxtaposing the secular and religious languages. Insofar as differences arose between traditional and new usage, where the traditional meaning was based on the language of church books, the differences were immediately seen in terms of an opposition between secular and religious. Given the iconic, non-conventional view of the sign, characteristic of the clergy's linguistic position in the first half of the nineteenth century, words in their traditional meaning were considered sacred, and in their secularized meaning profane, indeed the very process of secularizing word meanings was perceived as the sacrilegious desecration of sacred signs.

We should keep in mind, however, that the "secular" language was at the same time the "general" language, the language of the cultured elite, which the clergy could not help but to take into account. The dominating position of the secular literary language forced the writer or preacher to consider that the words he used in their "church" meaning might be understood by the audience according to accepted secular usage, and therefore the writer from the clergy had to continually try and avoid ambiguities. As Amfiteatrov cautioned in the passage cited above, "use words that have been profaned by worldly language carefully and with prudence" (Amfiteatrov, II,128-29). Filaret Drozdov, when editing the translation of some patristic writing, replaced a series of Slavonicisms "ambiguous (oboiudnykh) to contemporary understanding" with "somewhat new" words (Filaret, II, 273). The correction Filaret made to the akafist (akathistos hymn) to the Most Holy Virgin Mother may serve as an illustration of this. In a letter of March 17, 1860, to the Ober-Procuror of the Synod Count A. P. Tolstoi, Filaret suggested replacing "Оставиша Ирода, яко блядива" [they left Herod, as a babbler] with "Оставиша Ирода, яко празднослова" or “яко буесловяща," 
explaining that "this word now has a new, shameful meaning" (Filaret, SMO, IV, 510). ${ }^{52}$ Filaret clearly was taking into account the irreverent associations that might have arisen for people unversed in Church Slavonic.

This fear of ambiguity was symptomatic. It demonstrates that the consistent separation of the secular and religious literary languages was more a desired goal than an actual fact. The clergy was fighting for the devout purity of its language and for its differentiation from the "contaminated" language of secular literature, but at the same time was conscious that this was an impossible battle. Given the church's subordination to the state and the clergy's isolated and inferior social position it was unable to impose its own language on its flock, and therefore had to accede to the language of its congregants. From the mid-nineteenth century the special, exclusive literary language of the clergy began to break down. This process was caused both by attempts on the part of the clergy to break out of its isolation (in this connection, attempts were made to make religious literature more comprehensible and accessible to society) and to close the gap between the secular and religious languages, which was connected to a new Slavonicizing of the secular literary language in the second half of the century under the influence of new writers from the "raznochintsy."

Thus the special religious literary language existed for somewhat more than half a century. With its demise disappeared the last arena in which the connection between the linguistic and cultural parameters that had arisen in connection with Petrine cultural politics was still operative. Linguistic behavior now ceased to be a direct factor in the secularization and Europeanization of Russian culture, and the character of the literary language was, in its main features, essentially independent of cultural positions. The opposition between Church Slavonic and Russian, the secular and religious, and between what was Europeanized or traditional, which the Petrine reforms had posed and which had defined the significance of language in the cultural conflicts of the eighteenth and early nineteenth centuries, ceased to have relevance and receded into the past. Their opposition no longer influenced theories of language or changes in linguistic practice. It might still be preserved in particular forms that were literary relics or serve as the basis for stylization in works of belles-lettres, but in the Russian cultural and linguistic consciousness it was overtaken by new conflicts generated by the changing structure of post-Emancipation Russian society and its new cultural concerns. The nature of these new paradigms could serve as the

In Slavonic, the verb "блядити" meant "to err, deceive, prate, or lie" whereas the secularized meaning was unprintable (to whore). (Translator's note) 
2. Slavonicizing Purism and Its Reconceptualization in Religious Literatures

basis of a further special study, but they do not have a direct connection to the subject of the current one, which has attempted to trace the ways in which the cultural paradigms formed in the Petrine period were transformed, influencing the development of the language and taking on new meanings. 